\title{
NBSIR 83-2768
}

\section{Interim Report on NBS Thermal Integrity Diagnostic Tests on Eight GSA Federal Office Buildings}

\author{
U.S. DEPARTMENT OF COMMERCE \\ National Bureau of Standards \\ National Engineering Laboratory \\ Center for Building Technology \\ Washington, DC 20234
}

Prepared for:

ublic Building Service

eneral Services Administration

Jashington, DC 20405

100

156

$83-2768$

33 C.2 



\section{INTERIM REPORT ON NBS THERMAL INTEGRITY DIAGNOSTIC TESTS ON EIGHT GSA FEDERAL OFFICE BUILDINGS}

Richard A. Grot

Yui-May L. Chang

Andrew K. Persily

Jin B. Fang

U.S. DEPARTMENT OF COMMERCE

National Bureau of Standards

National Engineering Laboratory

Center for Building Technology

Washington, DC 20234

September 1983

Prepared for:

Public Building Service

General Services Administration

Washington, DC 20405

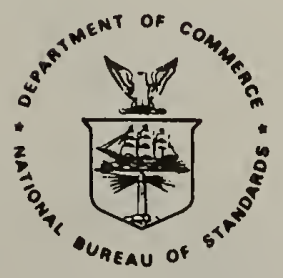

U.S. DEPARTMENT OF COMMERCE, Malcolm Baldrige, Secretary NATIONAL BUREAU OF STANDARDS, Ernest Ambler, Director 



\section{Abstract}

This report summarizes preliminary results of diagnostic tests to evaluate the thermal integrity of eight federal office buildings located throughout the country. The test results include tracer gas measurements of air infiltration rates, pressurization tests of the airtightness of the building shell, and inspections of the envelope employing infrared thermography. In addition, the thermal U-values of exterior walls were measured with both heat flow meters and a portable calorimeter box. The data collected on these buildings are still undergoing analysis and therefore are to be considered preliminary.

Key Words: air infiltration; building diagnostics; building thermal integrity; fan pressurization; field measurements; thermographic inspections; tracer gas techniques; U-value tests 


\section{Preface}

This work was sponsored by the Public Building Service of the General Serviceo Administration through an interagency agreement with the National Bureau of Standards, Interagency Agreement No. PBS-80-1. 


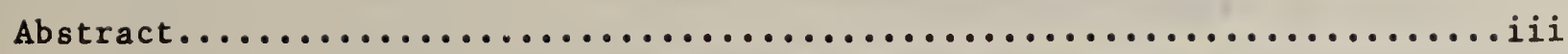

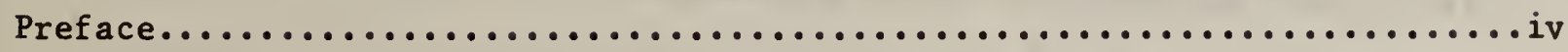

List of Tables............................................

List of Figures............................................

1. Introduction...........................................

2. Descriptions of the Buildings...............................

3. Air Infiltration and Building Tightness Tests..................10

4. Ground Infrared Thermographic Surveys........................21

4.1 Background

4.2 Summary of Results

5. Determination of the Thermal Resistances of the Building Envelope......39 Using Heat Flow Meters and a Portable Calorimeter

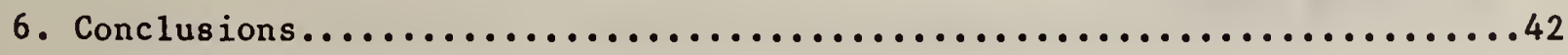

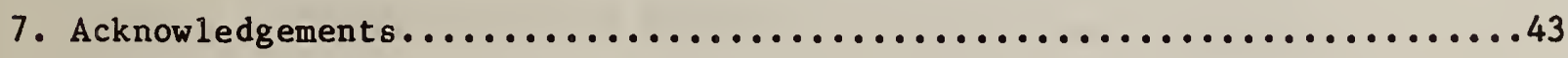

8. References..............................................44 


\section{List of Tables}

Table 1. Location of Tracer Gas Sampling

Table 2. Airtightness Measurements on the Buildings

Table 3. Typical One-Hour Decay Test for Anchorage

Table 4. Typical One-Hour Decay Test for Springfield

Table 5. Typical One-Hour Decay Test for Norfolk

Table 6. Typical One-Hour Decay Test for Huron

Table 7. Typical One-Hour Decay Test for Columbia

Table 8. Data Files for Ann Arbor Building with No Outbide Air Intake

Table 9. Data Files for Ann Arbor Building with Outside Air Intake

Table 10. Thermal Deficiencies Observed in Each Test Building

Table 11. Construction of External Walls of Test Buildings

Table 12. Comparison of Measured Wall Thermal Resistances and Corresponding Predicted Values 


\section{List of Figures}

Figure 1. Location of the Eight Federal Office Buildings

Figure 2. Schematic Diagram and Photograph of Federal Building in Anchorage

Figure 3. Schematic Diagram and Photograph of Federal Building in Springfield

Figure 4. Schematic Diagram and Photograph of Federal Building in Columbia

Figure 5. Schematic Diagram and Photograph of Federal Building in Norfolk

Figure 6. Schematic Diagram and Photograph of Federal Building in Pittsfield

Figure 7. Schematic Diagram and Photograph of Federal Building in Huron

Figure 8. Schematic Diagram and Photograph of Federal Building in Ann Arbor

Figure 9. Schematic Diagram and Photograph of Federal Building in Fayetteville

Figure 10. Natural Air Infiltration Rates Versus Induced Air Exchange Rate at $25 \mathrm{~Pa}$

Figure 11. Distribution of Surface to Volume Ratio Among Federal Buildings and Residences

Figure 12. Comparison of Ranks of Pressurization Test Results

Figure 13. Thermal Defects Observed in the Anchorage Building

Figure 14. Thermal Defects Observed in the Ann Arbor Building

Figure 15. Thermal Defects Observed in the Columbia Building

Figure 16. Thermal Defects Observed in the Fayetteville Building

Figure 17. Thermal Defects Observed in the Huron Building

Figure 18. Thermal Defects Observed in the Norfolk Building

Figure 19. Thermal Defects Observed in the Pittsfield Building

Figure 20. Thermal Defects Observed in the Springfield Building 



\section{Introduction}

In order to assess the usefulness of various diagnostic procedures for the assessment of the thermal integrity of the envelope of federal office buildings, the National Bureau of Standards performed a series of diagnostic tests on eight federal office builidnge during the period from September 1982 to May 1983. These buildings were located in Anchorage, AK, Columbia, SC, Norfolk, VA, Springfield, MA, Pittsfield, MA, Huron, SD, Ann Arbor, MI, and Fayetteville, AR. The tests which were performed on these buildings consisted of: fan pressurization to assess the tightness of the building envelope, tracer gas measurements of the natural air infiltration rates and ventilation rates of the buildings, ground based infrared thermography, aerial thermography, inspection of the buildings with spot radiometers, determination of the thermal conductance or U-value using heat flow meters and a portable calorimeter, and leakage testing of the components of the building. A detailed technical description of these test methods $c$ an be found in the report of the first phase of this project ${ }^{\text {. The }}$ purpose of the present report is to summarize the data collected and analyzed from the fan pressurization tests, the tracer gas tests, the thermographic inspections and the U-value tests. To date NBS has been able to carry out all tests envisioned in the first phase of this project with the exception of the use of the Envelope Thermal Testing Unit (ETTU) developed by Lawrence Berkeley Laboratories for measuring the dynamic response of walls. This device will not be available to NBS until the late summer of 1983.

\section{Description of the Buildings}

The eight federal office buildings are located in the cities shown in the map in figure 1. In general these are new buildings (less than 3 years old) constucted to the U.S. federal energy guidelines of less than $630 \mathrm{MJ} / \mathrm{m}^{2}$ per year of on-site energy and less than $1200 \mathrm{MJ} / \mathrm{m}^{2}$ per year of off-site energy. The building in Fayetteville, AR is 7 years old and was built before this energy guideline for new federal office buildings was in effect. Though these buildings tend to perform better than most existing federal office buildings, none has met the energy guidelines during its first few years of occupancy. For the purpose of this study the buildings in Anchorage, AK; Springfield, MA; Norfolk, VA; and Columbia, SC are considered large office buildings (over $10,000 \mathrm{~m}^{2}$ of occupiable floor area). Columbia is 15 stories high, Norfolk 8 stories, Anchorage between 2 and 6 depending on the module, and Springfield 5 stories. The buildings in Pittsfield, MA; Huron, SD; Ann Arbor, MI; and Fayetteville, AR are considered small office buildings (less than $10,000 \mathrm{~m}^{2}$ of floor area). These small office buildings range in height from 2 to 5 stories. Schematic diagrams and a photograph of each building are given in figures 2 through 9. All but two of the buildings have variable volume air handlers in the major zones of the buildings. They are heated by perimeter heating systems which are generally hydronic. The building in Columbia has two perimeter heating systems. In the Norfolk building, heaters and air conditioners have been added to the air system on floors which proved difficult to heat and cool. They all have central chiller systems for cooling the core spaces of the buildings. The buildings in Anchorage and Springfield have underground garages. The Norfolk building has an exterior garage. 


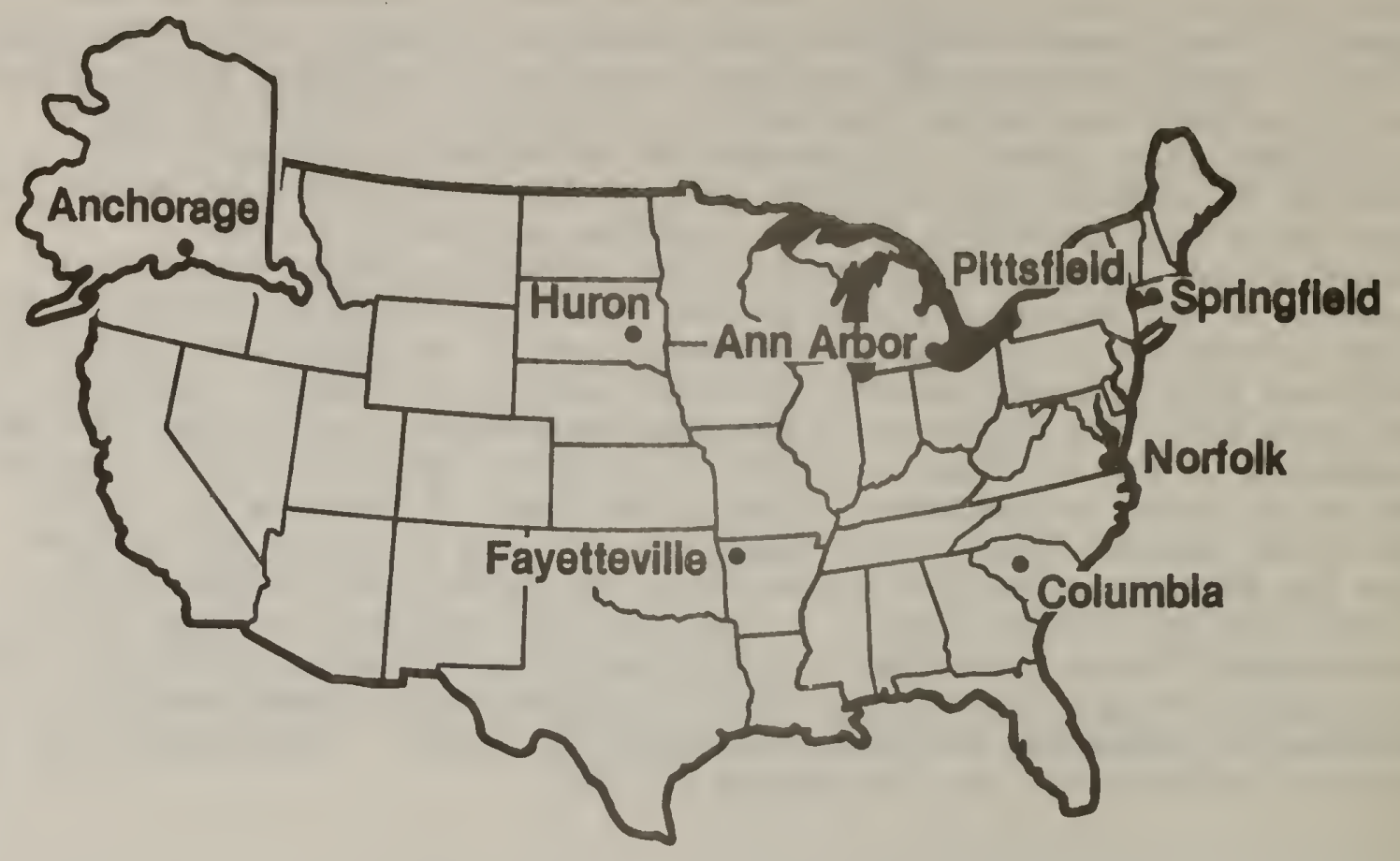

Figure 1. Location of the Eight Federal Office Buildings

ANCHORAGE FEDERAL BUILDING

Schematic of Overhead view
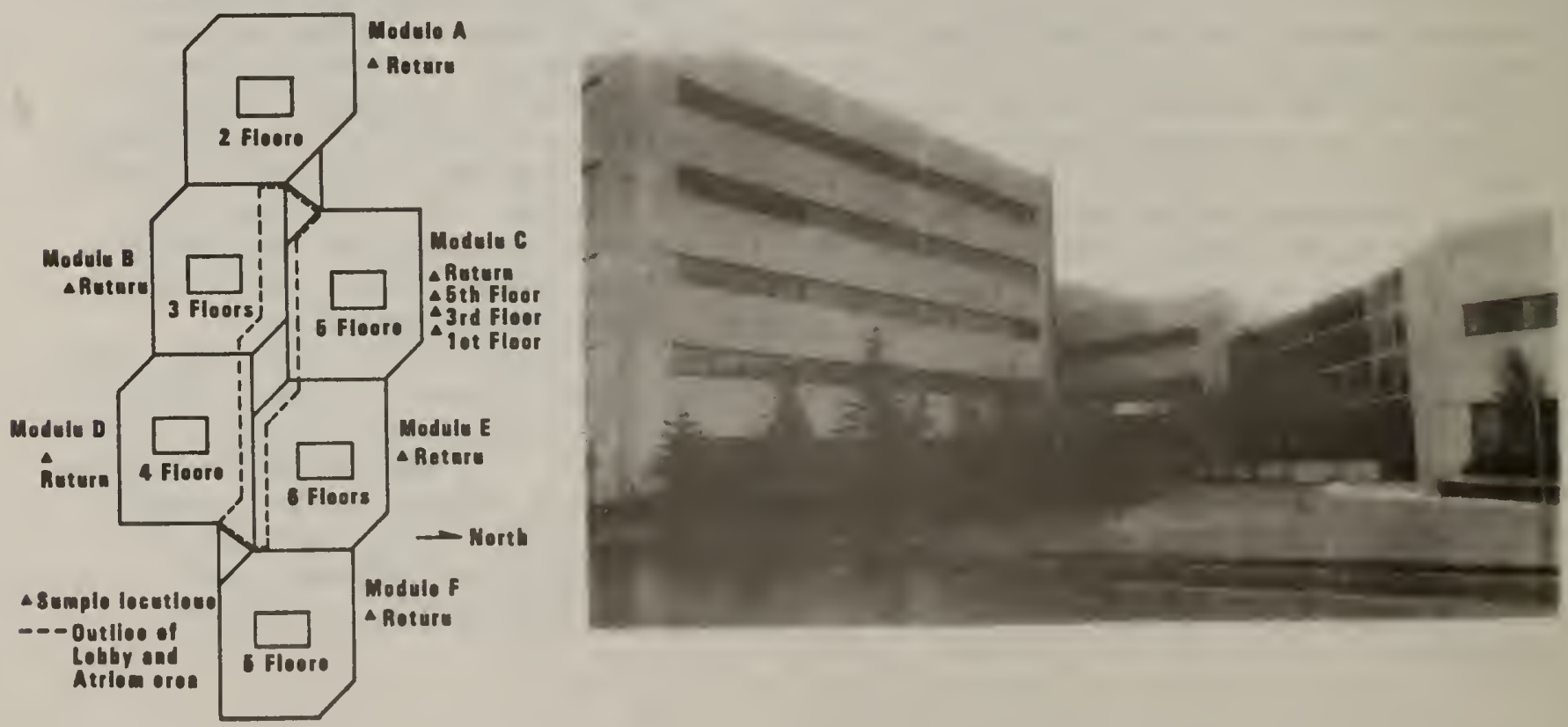

Figure 2. Schematic Diagram and Photograph of Federal Building in Anchorage, AR 


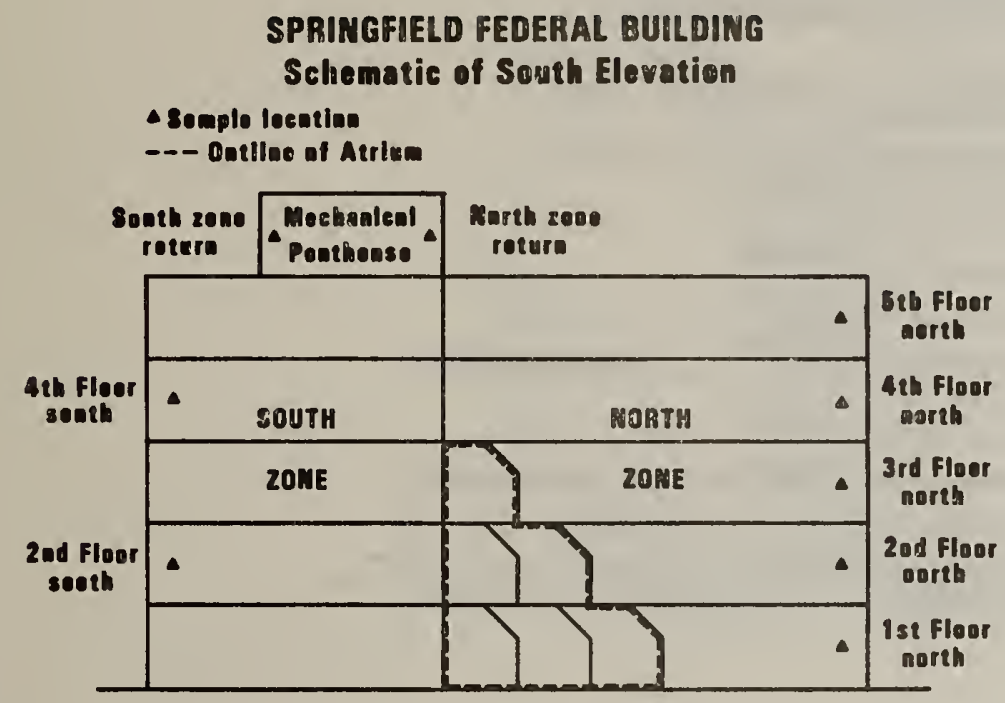

SPRINGFIELD FEDERAL BUILDING

Schematle of First Floor

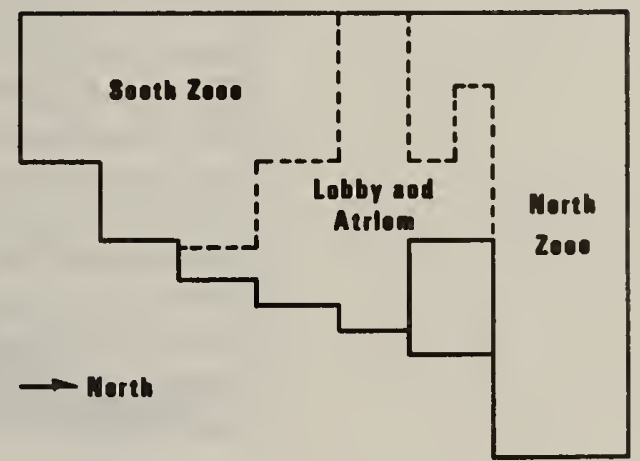

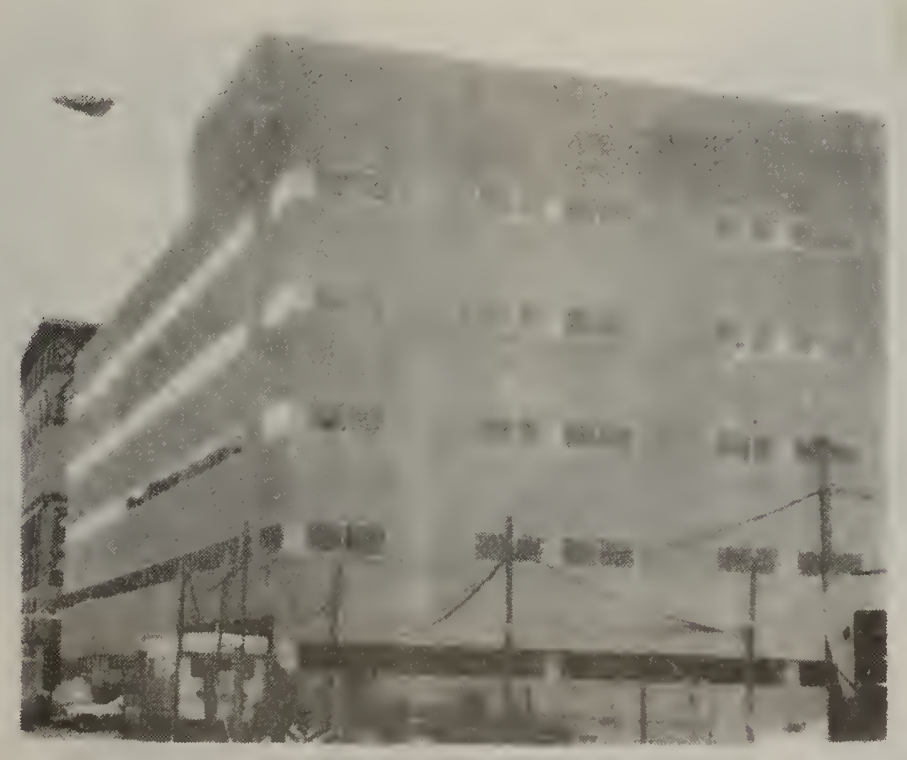

Figure 3. Schematic Diagram and Photograph of Federal Building in Springfield, MA 


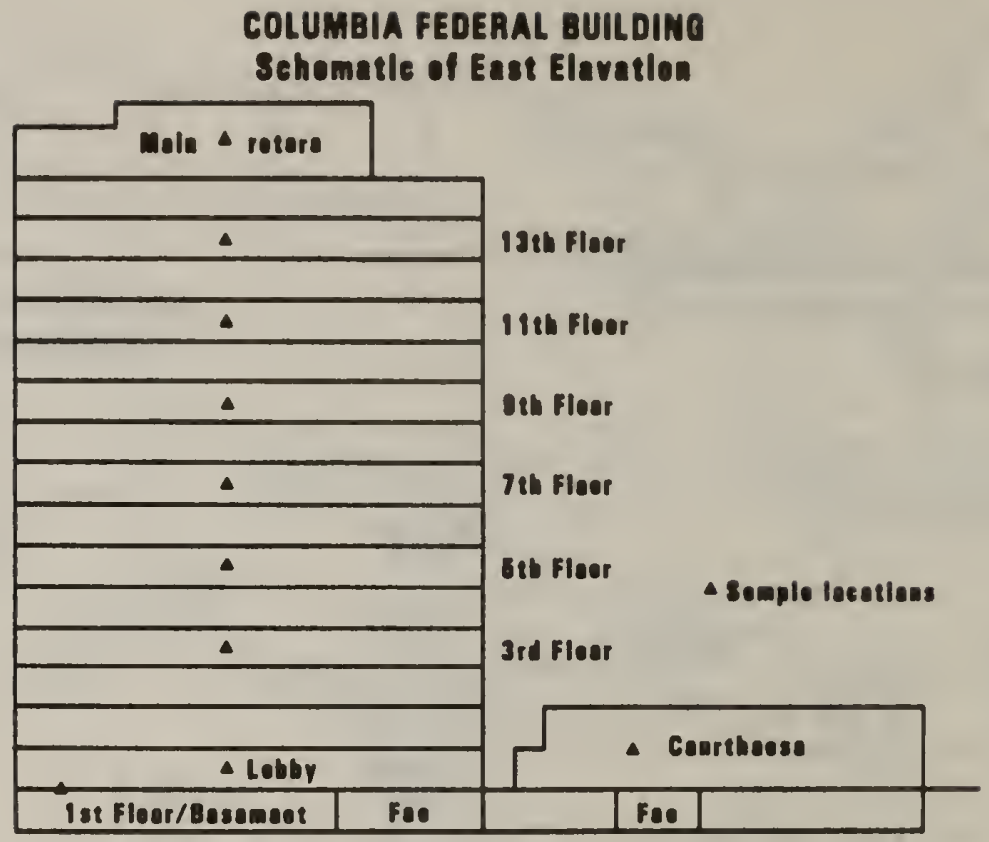

COLUMBIA FEDERAL BUILDING

Schematlc of Overhead Vlow

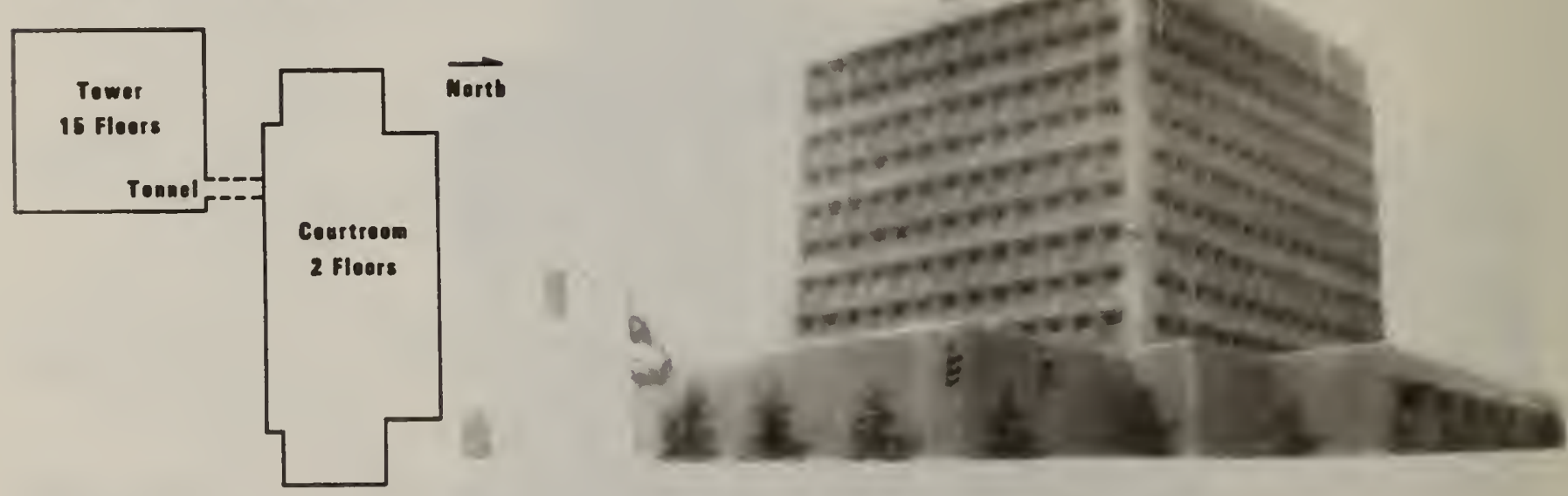

Figure 4. Schematic Diagram and Photograph of Bederal Building in Columbia, SC 


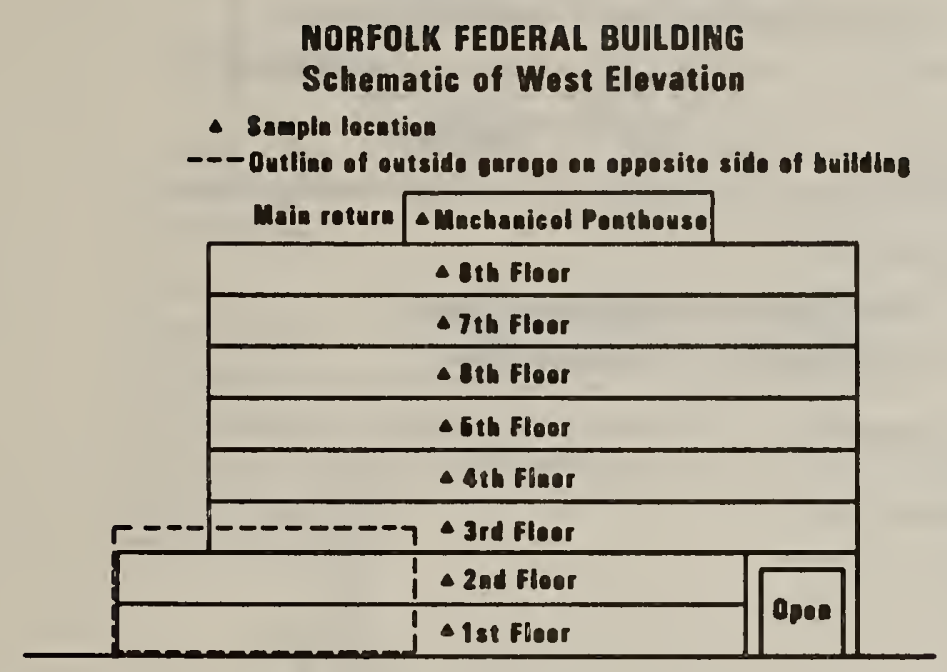

NORFOLK FEDERAL BUILDING

Schomatic of Morth Elevation
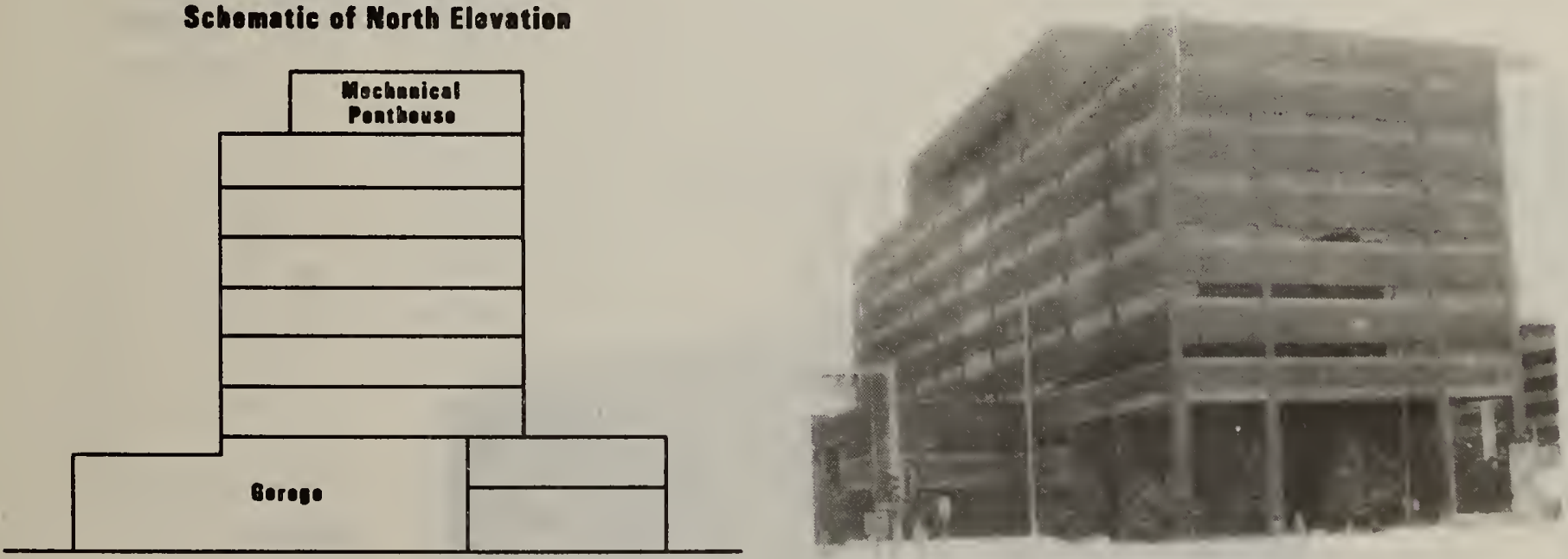

Figure 5. Schematic Diagram and Photograph of Federal Building in Norfolk, VA 
PITTSFIELD FEDERAL BUILDINO

Sehomatle of Wost Elovetion

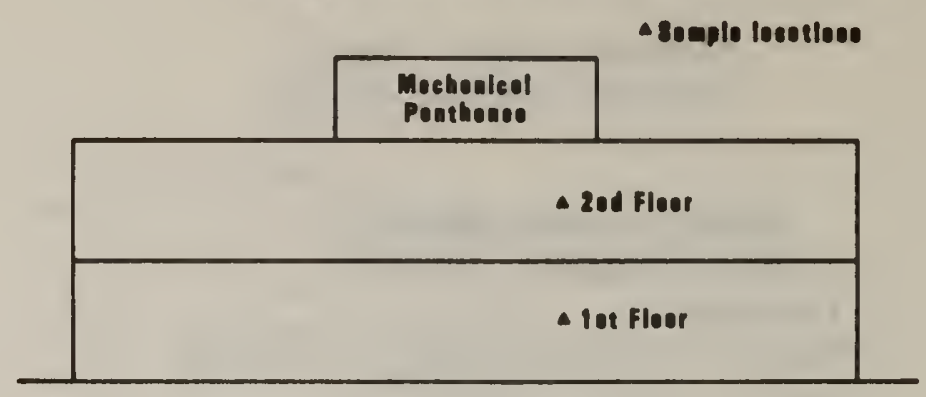

PITTSFIELD FEDERAL BUILDING

Schematic of Overhead Vlew
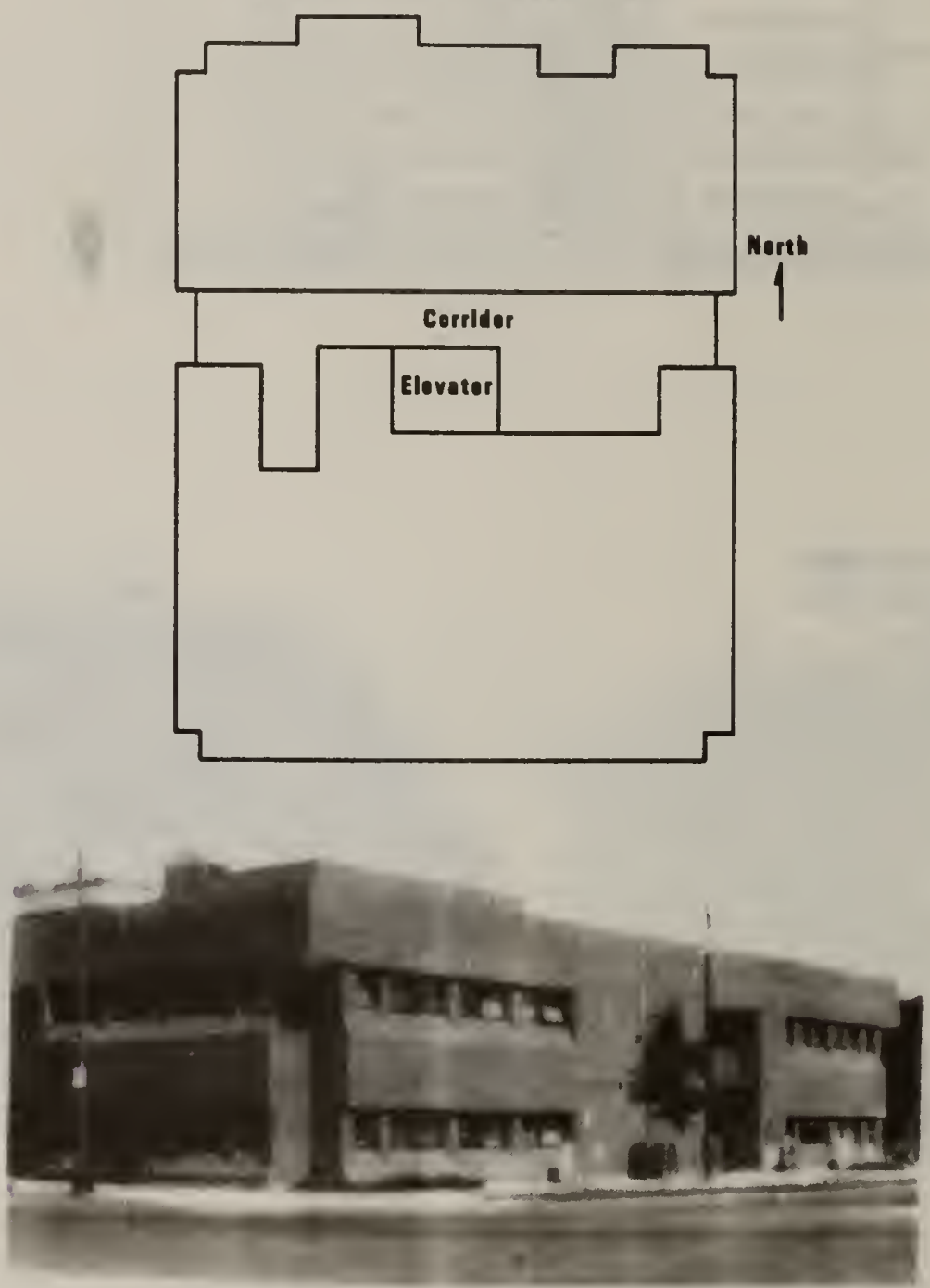

Figure 6. Schematic Diagram and Photograph of Federal Building in Pittsfield, MA 


\begin{tabular}{|c|c|c|}
\hline \multirow{2}{*}{$\begin{array}{r}\text { Sche } \\
\Delta \text { sampla laeatia }\end{array}$} & $\begin{array}{l}\text { HURON FEDERAL BUILDING } \\
\text { atic of East-West Buildin }\end{array}$ & \multirow[b]{2}{*}{ "East" Wlag } \\
\hline & $\begin{array}{l}\text { Mathenalcal Panthouss } \\
\text { Marth rotart East raturn }\end{array}$ & \\
\hline \multicolumn{2}{|c|}{ 4th Floor marth 4} & $\triangle$ Ath Floar aest \\
\hline \multicolumn{2}{|c|}{ 3rd Floor north 4} & A 3rd Floor aest \\
\hline \multicolumn{2}{|c|}{ 2ad Floor aorth 4} & $\triangle$ 2ad Floor aast \\
\hline \multicolumn{2}{|l|}{ Ist Floor north 4} & $\Delta$ Ist Floor enst \\
\hline
\end{tabular}

HURON FEDERAL BUILDING

Schematic of Overhead View

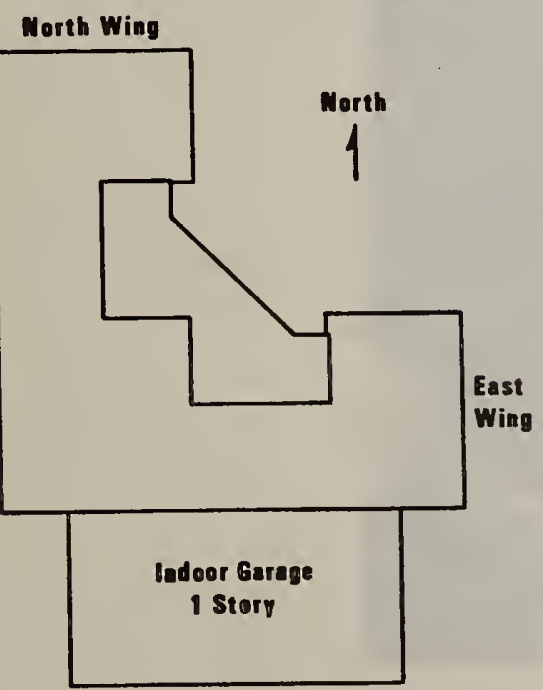

Figure 7. Schematic Diagram and Photograph of Federal Building in Huron, SD 
ANN ARBOR FEOERAL BUILDINO

Sehomotic of Flrst Floor
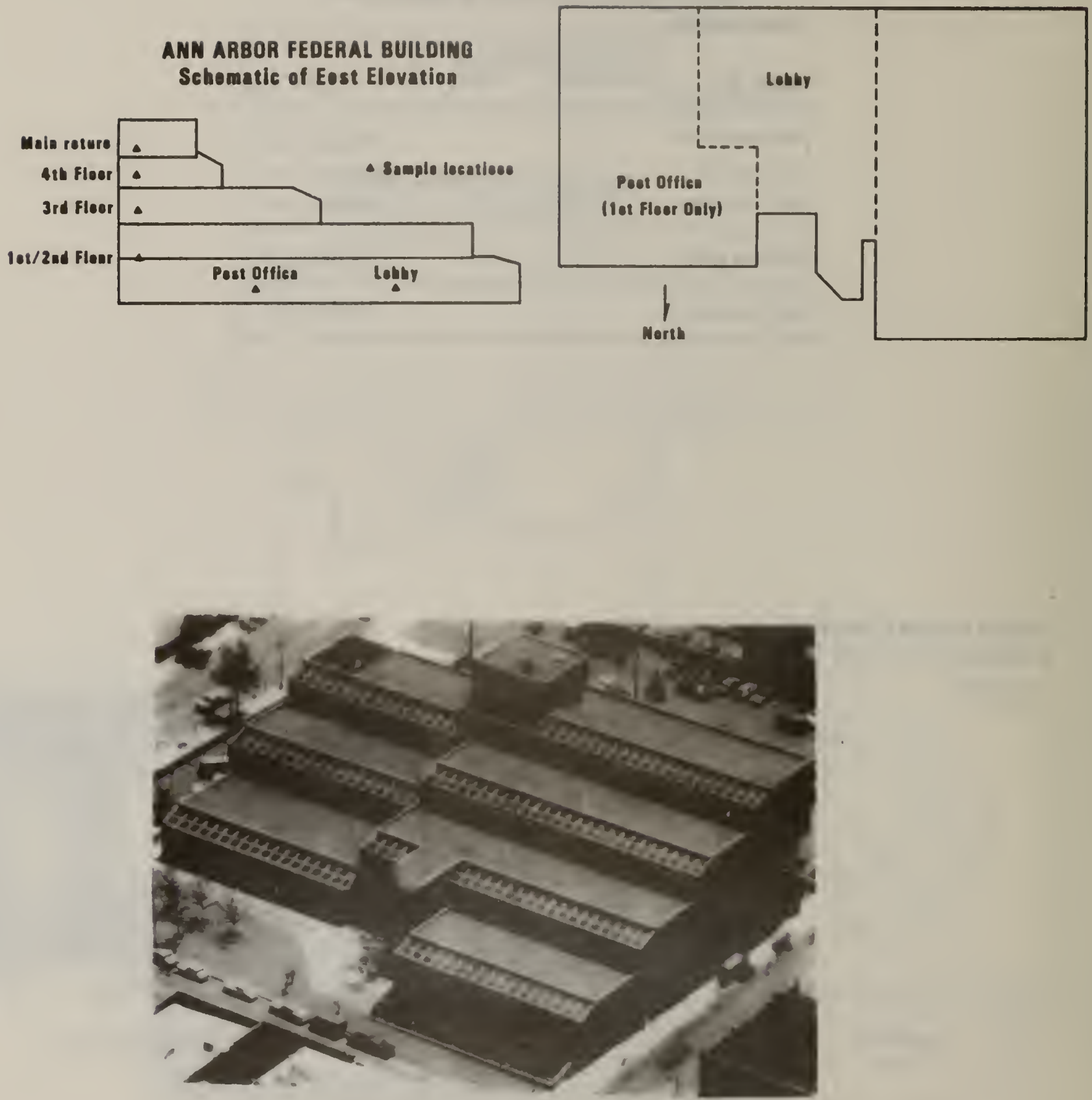

Figure 8. Schematic Diagram and Photograph of Federal Building in Ann Arbor, MI 
FAYETTEVILLE FEDERAL BUILDING

Schomatic of North Elovation

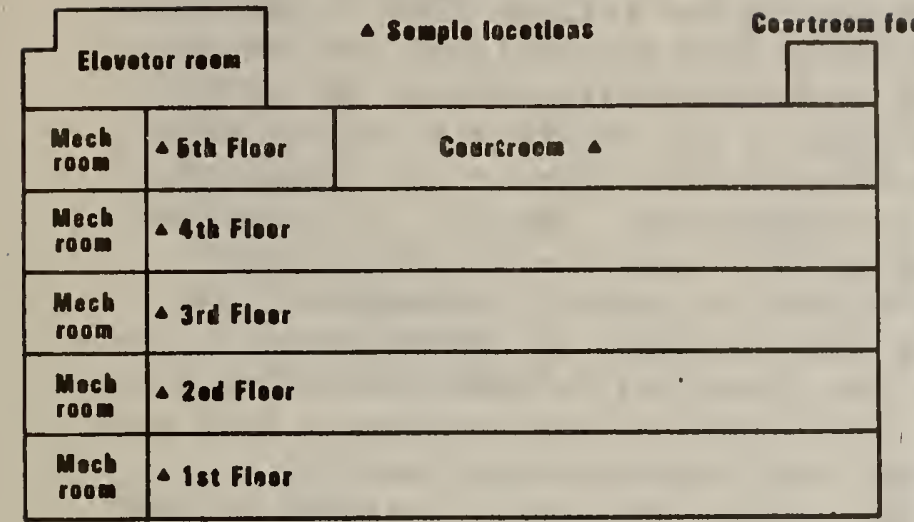

Sehematic of First Floor

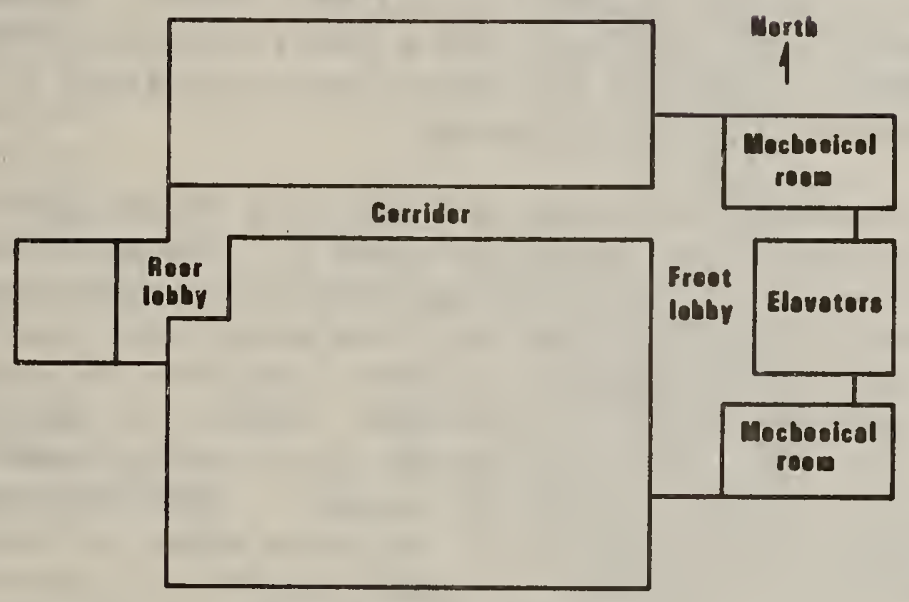

Schematic of Fifth Floor

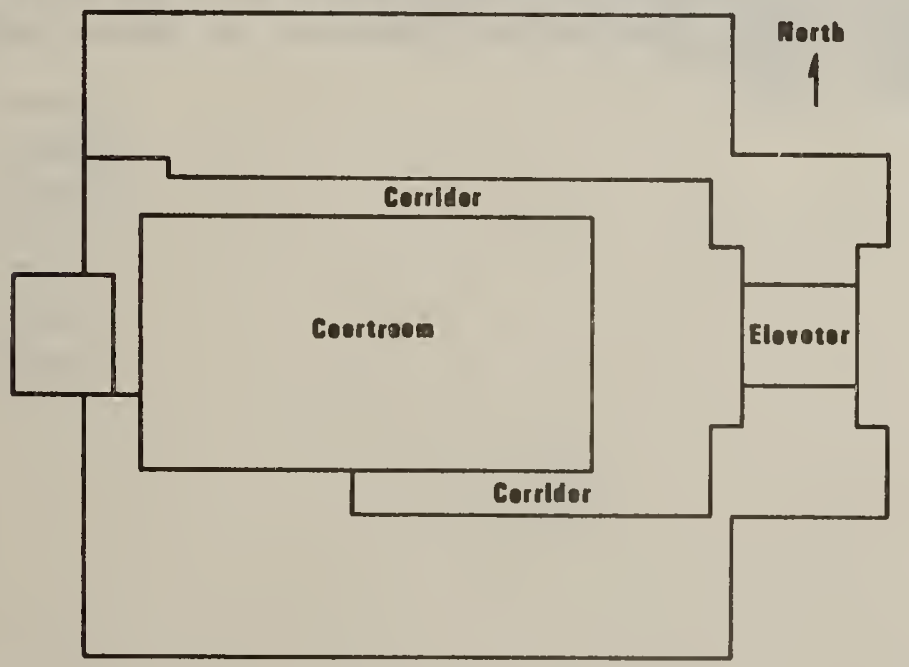

Figure 9. Schematic Diagram and Photograph of Federal Building in Fayetteville, AR 


\section{Air Infiltration and Building Tightness Tests}

The air infiltration and building tightness of the eight federal office buildings were tested using whole building fan pressurization and tracer gas techniques. The fan pressurization tests were performed during the fall of 1982 on seven of the eight federal buildings using the building $s$ HVAC system fans. It was not possible to pressurize the federal building in Fayetteville because the outside air duct could not bring in a sufficient volume of air due to its limited size. This building could be pressurized with an external fan however the shipment of this fan to Fayetteville was judged to be too expensive. The air infiltration under natural conditions was measured using sulfur hexafluoride $\left(\mathrm{SF}_{6}\right)$ as a tracer. This test was designed for each building to produce a measure of the total air infiltration rate of the building and the rates of the major zones of the building. Sample and injection tubing was installed in each zone along with wiring for measurng interior temperatures, the status of the building's HVAC fans and exterior weather conditions (wind speed, wind direction and exterior temperature). The automatic air infiltration system previously designed by NBS for large buildings was installed in each building for a period of about a week during the fall, winter and spring (three automated air infiltration systems were used on this project) ${ }^{2}$. Tests were performed both during periods of occupancy and non-occupancy, and with the dampers opened and closed. To date, tracer gas infiltration meaurements have been made for a total of about 200 hours in each building. The air sample locations for these tests are given in table 1, and shown in the schematics in figures 2 through 9.

The results of the pressurization tests and the fall tracer gas air infiltration measurements (dampers closed) are shown in table 2. The most notable aspect of these data is the tightness of the buildings from the pressurization measurements. The pressurization test results are the air flow rates into the buildings, in units of building volumes or exchanges per hour, required to sustain a $25 \mathrm{~Pa}$ pressure difference between inside and outside. These induced $25 \mathrm{~Pa}$ flow rates are significantly larger than the ventilation rates during normal building operation or infiltration rates induced by weather. The $50 \mathrm{~Pa}$ exchange rates of the buildings are roughly 1.5 times the $25 \mathrm{~Pa}$ rates shown in the table. These 50 $\mathrm{Pa}$ leakage rates are very low compared to those measured in homes. U.S. homes generally range from about 5 volumes per hour (tight) to greater than 20 (very leaky). Swedish and Canadian homes are being built with $50 \mathrm{~Pa}$ flow rates of less than 2 volumes per hour. Thus, the $50 \mathrm{~Pa}$ flow rates of these federal buildings correspond to very tight homes. 
Table 1. Location of Tracer Gas Sampling

Anchorage

1. Module A

2. Module B

3. Module C

4. Module D

5. Module E

6. Module F

7. 5th F1oor Module C

8. 3rd Floor Module C

9. lst Floor Module C

\section{Springfield}

1. North Return

2. South Return

3. Atrium/Lobby

4. 5th F1oor - North

5. 4th Floor - North

6. 3rd Floor - North

7. 2nd Floor - North

8. lst Floor - North

9. 4th Floor - South

10.2nd F1oor - South

Ann Arbor

1. HVAC Return

2. 4th Floor Return

3. 3rd Floor Return

4. 1st \& 2nd Floor Return

5. Lobby

6. Post Office

\section{Huron}

1. North Return

2. East Return

3. 4th Floor - North

4. 3rd Floor - North

5. 2nd Floor - North

6. 1st Floor - North

7. 4th Floor - East

8. 3rd Floor - East

9. 2nd F1oor - East

10.1st Floor - East
Columbia

1. HVAC Return

2. 13th Floor

3. 11th Floor

4. 9th Floor

5. 7th Floor

6. 5th Floor

7. 3rd Floor

8. 1st Floor \& Basement

9. Lobby

10. Courthouse

Norfolk

1. HVAC Return

2. 8 th Floor

3. 7 th Floor

4. 6th F1oor

5. 5th Floor

6. 4th Floor

7. 3rd Floor

8. 2nd Floor

9. lst Floor

\section{Fayetteville}

1. 1st Floor

2. 2nd F1oor

3. 3rd Floor

4. 4th Floor

5. 5th Floor

6. Courtroom - 5th Floor

Pittsfield

1. lst F1oor Return

2. 2nd Floor Return 
Table 2. Airtightness Measurements on the Federal Buildings

$\begin{array}{lccc}\begin{array}{l}\text { Building } \\ \text { Location }\end{array} & \begin{array}{c}\text { Floor Area } \\ \left(\mathrm{m}^{2}\right)\end{array} & \begin{array}{c}\text { Pressurization } \\ \text { Flow at } 25 \mathrm{~Pa} \\ (\text { volumes/hour) }\end{array} & \begin{array}{c}\text { Tracer Gas Decay } \\ \text { Infiltration Rate } \\ \text { (volumes/hour) }\end{array} \\ \begin{array}{l}\text { Anchorage } \\ \text { Ann Arbor }\end{array} & 4,9,490 & 0.80 & 0.20 \text { to } 0.30 \\ \text { Columbia } & 20,070 & 0.86 & 0.55 \text { to } 0.65 \\ \text { Fayetteville } & 3,400 & 0.67 & 0.35 \text { to } 0.45 \\ \text { Huron } & 6,420 & -1,900 & 0.35 \text { to } 0.45 \\ \text { Norfolk } & 17,250 & 0.45 & 0.10 \text { to } 0.20 \\ \text { Pittsfield } & 1,730 & 1.36 & 0.45 \text { to } 0.55 \\ \text { Springfield } & 13,530 & 1.07 & 0.25 \text { to } 0.35\end{array}$

* The values listed correspond to a range of measured infiltration rates with wind speeds less than $1.5 \mathrm{~m} / \mathrm{s}$ and an outside temperature between 5 and $10{ }^{\circ} \mathrm{C}$. 


\section{Table 1. Location of Tracer Gas Sampling}

Anchorage

1. Module A

2. Module B

3. Module C

4. Module D

5. Module E

6. Module F

7. 5th Floor Module C

8. 3rd Floor Module C

9. 1st Floor Module C

\section{Springfield}

1. North Return

2. South Return

3. Atrium/Lobby

4. 5th Floor - North

5. 4th Floor - North

6. 3rd Floor - North

7. 2nd Floor - North

8. 1st Floor - North

9. 4th Floor - South

10.2nd Floor - South

\section{Ann Arbor}

1. HVAC Return

2. 4th Floor Return

3. 3rd Floor Return

4. 1st \& 2nd Floor Return

5. Lobby

6. Post office

\section{Huron}

1. North Return

2. East Return

3. 4th Floor - North

4. 3rd Floor - North

5. 2nd Floor - North

6. lst Floor - North

7. 4th Floor - East

8. 3rd Floor - East

9. 2nd Floor - East

10.1st Floor - East
Columbia

1. HVAC Return

2. 13th Floor

3. 11 th Floor

4. 9 th Floor

5. 7th Floor

6. 5th Floor

7. 3rd Floor

8. 1st Floor \& Basement

9. Lobby

10. Courthouse

Norfolk

1. HVAC Return

2. 8th Floor

3. 7 th Floor

4. 6th Floor

5. 5th Floor

6. 4th Floor

7. 3rd Floor

8. 2nd Floor

9. 1st Floor

Fayetteville

1. 1st Floor

2. 2nd Floor

3. 3rd Floor

4. 4th Floor

5. 5th Floor

6. Courtroom - 5th Floor

Pittsfield

1. lst Floor Return

2. 2nd Floor Return 
Table 2. Airtightness Measurements on the Federal Buildings

\begin{tabular}{|c|c|c|c|}
\hline $\begin{array}{l}\text { Building } \\
\text { Location }\end{array}$ & $\begin{array}{c}\text { Floor Area } \\
\left(\mathrm{m}^{2}\right)\end{array}$ & $\begin{array}{l}\text { Pressurization } \\
\text { Flow at } 25 \mathrm{~Pa} \\
\text { (volumes/hour) }\end{array}$ & $\begin{array}{l}\text { Tracer Gas Decay* } \\
\text { Infiltration Rate } \\
\text { (volumes/hour) }\end{array}$ \\
\hline Anchorage & 45,490 & 0.80 & 0.20 to 0.30 \\
\hline Ann Arbor & 4,900 & 0.86 & 0.55 to 0.65 \\
\hline Columbia & 20,070 & 0.67 & 0.35 to 0.45 \\
\hline Fayetteville & 3,400 & --- & 0.35 to 0.45 \\
\hline Huron & 6,420 & 0.45 & 0.10 to 0.20 \\
\hline Norfolk & 17,250 & 1.36 & 0.45 to 0.55 \\
\hline Pittsfield & 1,730 & 1.07 & 0.25 to 0.35 \\
\hline Springfield & 13,530 & 1.00 & 0.30 to 0.40 \\
\hline
\end{tabular}

* The values listed correspond to a range of measured infiltration rates with wind speeds less than $1.5 \mathrm{~m} / \mathrm{s}$ and an outside temperature between 5 and $10^{\circ} \mathrm{C}$. 
Table 7. Typical One-Hour Decay Tests for Columbia

FEDERAL BUILDING - COLUMBIA
MAX CURRENT $=1708$

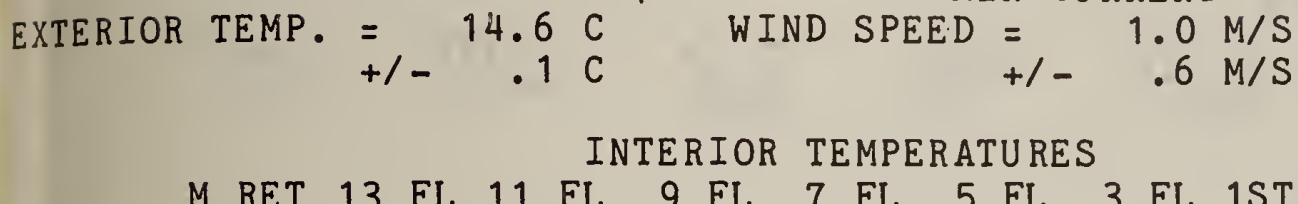

WIND DIR. $=157$. DEG.

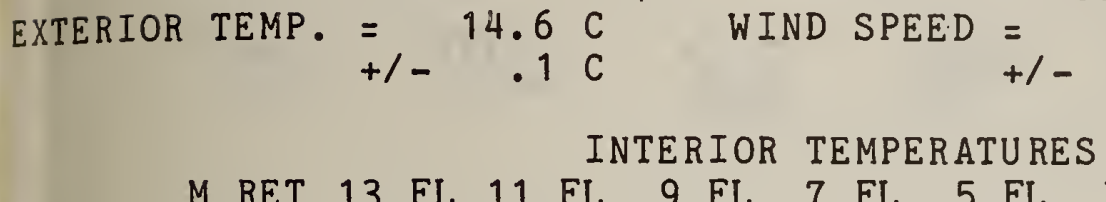

$M$ RET 13 FL 11 FL 9 FL 7 FL 5 FL 3 FL 1ST-B LOBBY COURT

$\begin{array}{lllllllllll}27.6 & 27.7 & 27.2 & 27.5 & 27.2 & 26.6 & 26.3 & 22.2 & 21.7 & 24.3 & \mathrm{C}\end{array}$

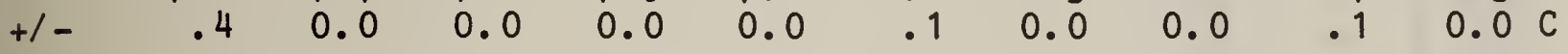

HVAC FAN OPERATION

TOWER 1ST-BAS COURT

$$
\begin{array}{cccc}
0 & 0 & 0 & \text { SEC }
\end{array}
$$

TRACER CONCENTRATIONS

$0: 00$

$0: 10$

$0: 20$

$0: 30$

$0: 40$

INFIL
$M$ RET $13 \mathrm{FL} 11 \mathrm{FL} 9 \mathrm{FL} 7 \mathrm{FL} 5$

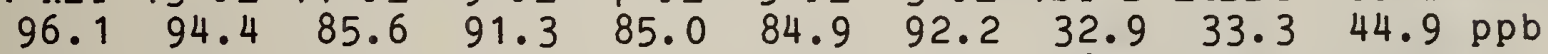

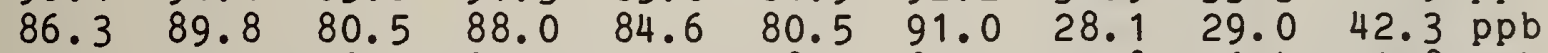

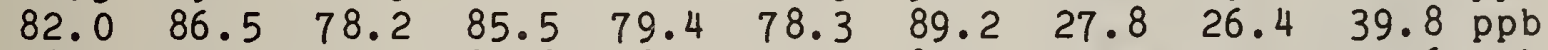

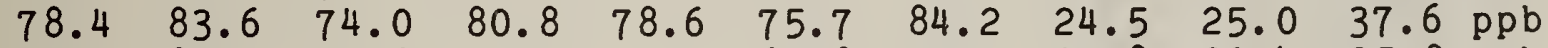

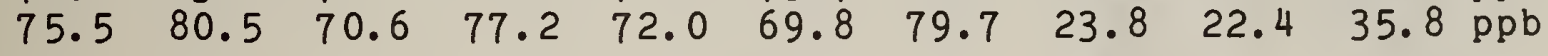
$\begin{array}{lllllllllll}.27 & .22 & .27 & .27 & .30 & .28 & .27 & .37 & .50 & .34 & / \mathrm{HR}\end{array}$ 
Table 8. Data File for Ann Arbor Building with No Outaide Air Intake

\section{CITY AND BUILDING : FEDERAL BUILDING - ANNARBOR}

CONDITION : O\% OUTSIDE AIR

CONDITION : VENTS UNSEALED

CONDITION : WIND DATA

$\begin{array}{rlr}\text { DATE } & \text { HOUR } & \text { W. SPEED } \\ \text { 2) } 4 / 83 \text { 18 } & & 1.4 \\ \text { HVAC } & =.47 \\ \text { 4THF } & =.71 \\ \text { 3RD F } & =.39 \\ \text { 1\&2 F } & =.57 \\ \text { LOB. } & =.76 \\ \text { P.O. } & =2.28\end{array}$

DATE HOUR W.SPEED

2/ $4 / 83$

W. DIR

270.0
T. IN

22.9
T. DIFF

21.5

AI. AVE .86

HVAC $=1.24$
4 THF $=1.01$
3RDF $=.54$
$1 \& 2 F=.52$
LOB. $=.97$
P.O. $=1.43$

DATE HOUR W.SPEED

2) $4 / 8320$ W.SPEED W.DIR

T. OUT

1.5

T. IN

T. DIFF

AI. AVE

270.0

1.8

20.9

.95

HVAC $=.62$
4THF $=.42$
3RDF $=.62$
1\&2 F $=.58$
LOB. $=1.22$
P.O. $=1.37$

DATE HOUR W.SPEED 2/ $4 / 83$

1. 0

W. DIR

T. OUT

T. IN

T. DIFF

20.8

AI. AVE

.822 .3

T. DIFF

21.0

AI. AVE

22.5

.81

HV AC $=$
3RDF $=.54$
$1 \& 2 F=1.64$
LOB. $=1.53$
P.O. $=1.26$

DATE HOUR W.SPEED

$\begin{array}{cccc}2 / 4 / 83 & 22 & .8 & 270.0\end{array}$

T. OU T

1. 4

T. IN

22. 1

T.DIFF 20.7

AI. AVE

HVAC $=.61$
4THF $=.57$
3RDF $=.64$
1\&2 F $=.62$
LOB. $=1.27$
P.O. $=1.23$


Table 8. Data Files for Aan Arbor Building with No Out ide Air Intake CITY AND BUILDING : FEDERAL BUILDING - ANNARBOR

CONDITION : O\% OUTSIDE AIR

CONDITION : VENTS UNSEALED

CONDITION : WIND DATA

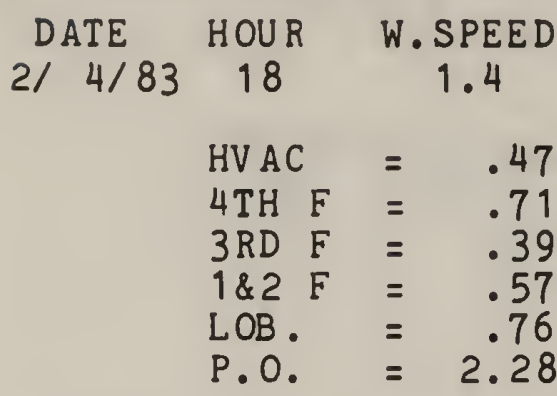

DATE HOUR W.SPEED

2) $4 / 83 \quad 19$

1.1

W. DIR

270.0

T. OU T

1.8

T. IN

22.9

T. DIFF

21.5

AI. AVE

1.4

22.9

.86

T. IN

22.7

T. DIFF

20.9

AI. AVE

.95

HVAC $=1.24$
$4 \mathrm{THF}=1.01$
3RDF $=.54$
$1 \& 2 \mathrm{~F}=.52$
LOB. $=.97$
P.O. $=1.43$

DATE HOUR W.SPEED

2) $4 / 8320 \quad 1.0$

W.DIR

T. OU T

1.5

HVAC $=.62$
4THF $=.42$
3RDF $=.62$
1\&2 F $=.58$
LOB. $=1.22$
P.O. $=1.37$

DATE HOUR W.SPEED

2/ $4 / 8321 \quad 1.0$

HVAC $=.54$
3RD F $=.64$
$1 \& 2 \mathrm{~F}=1.66$
LOB. $=1.53$
P.O. $=1.26$

DATE HOUR W.SPEED

2/ $4 / 83 \quad 22 \quad .8$

W. DIR

270.0

T. OUT

T. IN

.822 .3

T.DIFF

AI. AVE

20.8

.93

$\mathrm{HVAC}=.61$

$4 \mathrm{THF}=.57$

$3 R D=.64$

$1 \& 2 \mathrm{~F}=.62$

LOB. $=1.27$

P.O. $=1.23$

W. DIR

270.0

T. OUT

1.4

T. IN

T. DIFF $22.1 \quad 20.7 \quad .82$

AI. AVE 
The results of the tracer gas tests in table 2 indicate that the buildings in Pittsfield, Huron and Anchorage are experiencing relatively low natural leakage rates. The buildings with the highest natural rates are Ann Arbor and Norfolk. Tables 3 through 7 show the results of typical one-hour decay tests for the buildings in Anchorage, Springfield, Norfolk, Huron and Columbia. These tables indicate the extent of tracer gas mixing obtained in these tests, with good mixing being a requirement for accurate results. They also show zones of the building which exhibit high air exchange rates compared to the rest of the building - the lobby in Springfield, the lst floor in Norfolk, and the lobby in Columbia. Similar high rates can also be shown for the lst floor in Fayetteville and the lobby and post office in Ann Arbor. The lobbies generally exhibit larger exchange rates due to the exterior doors in these zones and the people moving in and out of the building. The post office in Ann Arbor has a large amount of such pedestrian traffic, and large doors for loading and unloading mail.

The data in tables 3 to 7 are checked for accuracy and then stored in separate files according to the condition of the vents and occupancy of the building. Tables 8 and 9 show data from these files for the Ann Arbor building. Note the large ventilation rates in table 9. These rates were measured under spring conditions in which the outdoor air is cool enough to condition the building without running the chillexs.

From the data in table 2, it can be seen that there is correlation between the pressurization measurements and the tracer gas test results. Bearing in mind that the tracer gas results are preliminary and made only under approximately the same weather conditions, infiltration rates have been plotted against pressurization results in figure 10. The correlation between the two measurements appears to be fairly strong. The slope of a line passing through all the points is roughly 0.5. If one adjusts the $25 \mathrm{~Pa}$ flows to $50 \mathrm{~Pa}$ flows using the rough correction factor of 1.5 , then the slope of infiltration against $50 \mathrm{~Pa}$ flow is about 1/3. This compares to the slope for residential buildings of about $1 / 20$.

In comparing the pressurization test results of the federal buildings to each other and to residential buildings, the important factor of surface to yolume ratio arises. Figure 11 shows the surface to volume ratios $(\mathrm{S} / \mathrm{V})$ in $\mathrm{m}^{-1}$ for the federal buildings and two sample homes. The 1 -story house is assumed to have a $110 \mathrm{~m}^{2}$ square floor area and $2.5 \mathrm{~m}$ ceilings. The 2-story home also has a square floor plan with $100 \mathrm{~m}^{2}$ on each floor and a $5 \mathrm{~m}$ building height. We see in the figure that the large sizes of the federal buildings generally lead to lower values of $\mathrm{S} / \mathrm{V}$ than for homes. The Anr Arbor building is an exception due to its particular design (see figure 8 ).

One may adjust the pressurization test results in table 1 to take into account the different values of $\mathrm{S} / \mathrm{V}$ among the buildings. Table 2 gives the $25 \mathrm{~Pa}$ leakage rate in building volumes per hour. This number divided by $\mathrm{S} / \mathrm{V}$, yields the $25 \mathrm{~Pa}$ flow rate in $\mathrm{m}^{3} / \mathrm{hr}$ per $\mathrm{m}^{2}$ of exterior surface area. This second $\mathrm{flow}$ rate is more of a measure of "construction quality" than the first flow rate. Figure 12 compares these two measures of leakiness. The vertical scale on the left shows the $25 \mathrm{~Pa}$ flows in exchanges per hour for the seven federal buildings and the two sample houses ( 2.0 exchanges/hr at $50 \mathrm{~Pa}$ very tight). The vertical scale on the right shows the $25 \mathrm{~Pa}$ flows in $\mathrm{m}^{3} / \mathrm{hr}-\mathrm{m}^{2}$ as discussed above. We see that in moving from exchanges/hr to $\mathrm{m}^{3} / \mathrm{hr}-\mathrm{m}^{2}$ the tightness ranking of the buildings changes significantly. Also, the spread in the leakage values using the second measure is larger than the spread in exchanges per hour. The most significant 
change occurs in the Ann Arbor bullding which is of average tightyes measured by exchanges per hour but is the tightest building in term of $\mathrm{m}^{3} / \mathrm{hr}-\mathrm{m}^{2}$. Thus, the Ann Arbor building has the tightest conetruction per $\mathrm{m}^{2}$ of wall area, but its design leads it to appear relatively leakier than many of the other building as meacured by the flow in exchanges per hour. 
Table 3. Typical One-Hour Decay Test for Anchorage

FEDERAL BLDG. - ANCHORAGE
MAX CURRENT $=1750$ MIN CU

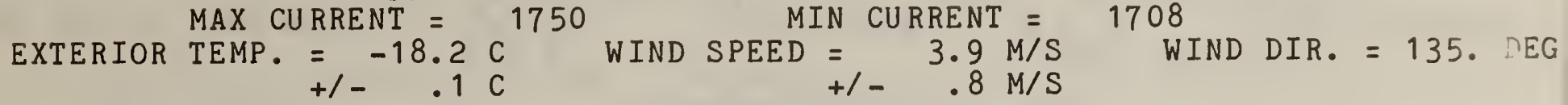

INTERIOR TEMPERATURES

MOD A MOD B MOD C MOD D MOD E MOD F 1 ST C 3RD C 5TH C

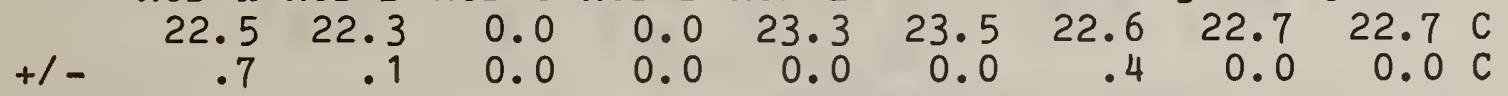

$\begin{array}{lrrrrrr}\text { HVAC FAN OPERATION } & & & \\ \text { MOD A } & \text { MOD B } & \text { MOD C } & \text { MOD D } & \text { MOD E } & \text { MOD F } & \\ 3599 & 3599 & 3599 & 3599 & 3599 & 3599 & \text { SEC }\end{array}$

TRACER CONCENTRATIONS

MOD A MOD B MOD C MOD D MOD E MOD F 1 ST C 3RD C 5TH C

$\begin{array}{lllllllllll}12: 00 & 114.6 & 108.9 & 101.1 & 91.8 & 78.2 & 81.4 & 68.2 & 86.5 & 103.3 & \mathrm{ppb}\end{array}$

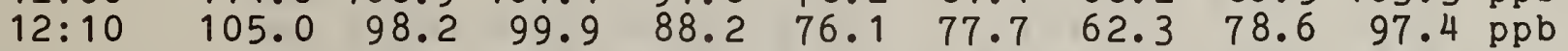

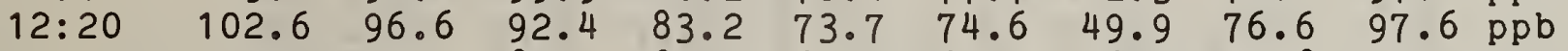

$\begin{array}{llllllllll}12: 30 & 93.9 & 90.1 & 89.3 & 82.2 & 69.2 & 69.2 & 46.3 & 72.8 & 130.3 \mathrm{ppb}\end{array}$

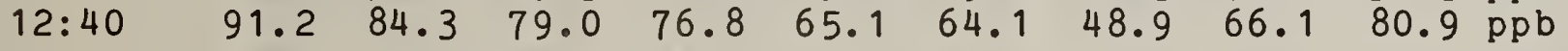

$\begin{array}{lllllllllll}\text { INFIL } & .31 & .32 & .44 & .26 & .32 & .39 & .48 & .34 & .16 & / H R\end{array}$

Table 4. Typical One-Hour Decay Test for Springfield

FEDERAL BLDG. - SPRINGFIELD, M M MAX CURRENT $=1862$
MIN CURRENT $=1810^{12 / 2 / 82} 0$

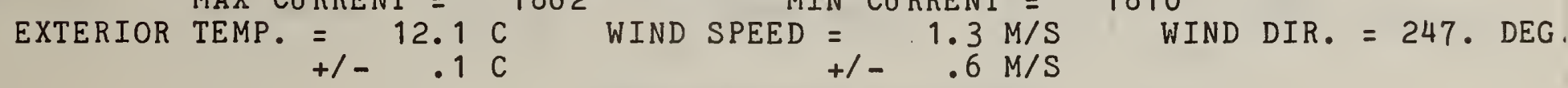

INTERIOR TEMPERATURES

NORTH SOUTH LOBBY $N$ 5TH N 4 TH N 3RD N 2ND N 1ST S 4TH S 2ND

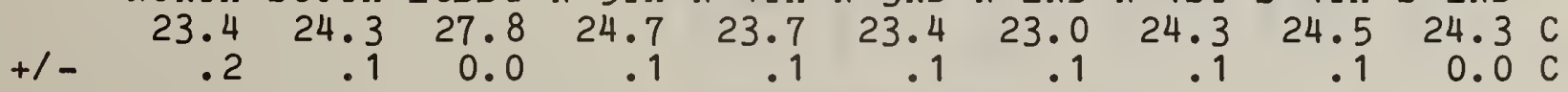

$$
\begin{array}{ccccc}
\multicolumn{4}{c}{\text { HVAC FAN }} & \text { OPERATION } \\
0 & \text { NORTH } & \text { SOUTH } & \text { ATRIUM } & \\
0 & 0 & 0 & 0 & \text { SEC }
\end{array}
$$

TRACER CONCENTRATIONS

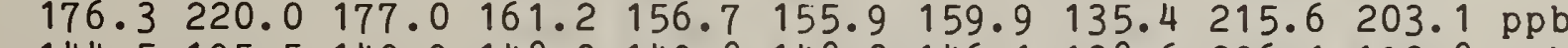

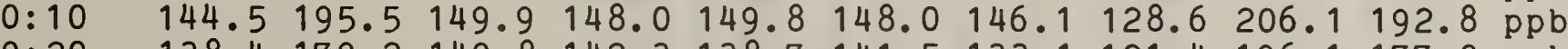

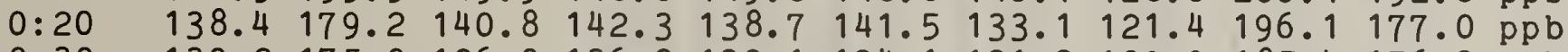

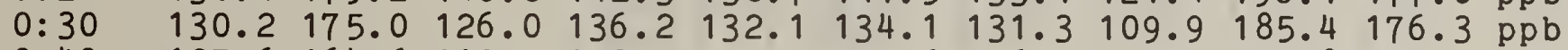

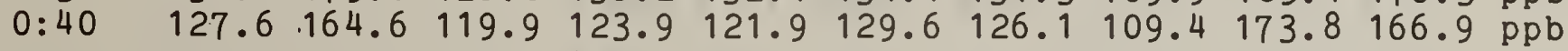

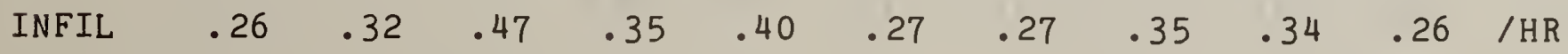




\section{Table 5. Typical One-Hour Decay Test for Norfolk}

$$
\begin{aligned}
& \text { FEDERAL BUILDING - NORFOLK VA }
\end{aligned}
$$

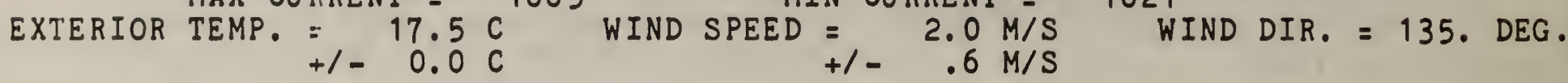

$$
\begin{aligned}
& \text { INTERIOR TEMPERATURES } \\
& \text { RET 8TH F 7TH F 6TH F 5TH F 4TH F 3RD F 2ND F 1ST F }
\end{aligned}
$$

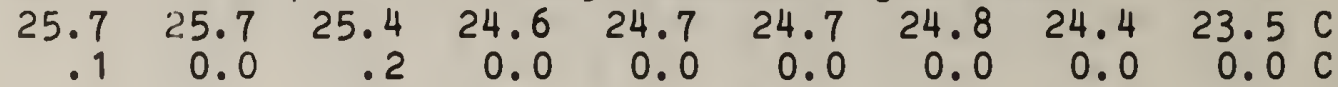

$$
\begin{aligned}
& M \text { HVAC } 1 \text { ST FL } \\
& \text { HVAC FAN OPERATION } \\
& 0 \quad 0 \quad \text { SEC } \\
& \text { TRACER CONCENTRATIONS }
\end{aligned}
$$

$\begin{array}{lllllllllll}\text { INFIL } & .43 & .42 & .36 & .36 & .38 & .51 & .38 & .57 & 1.17 & / \mathrm{HR}\end{array}$

Table 6. Typical One-Hour Decay Test for Huron

FEDERAL BUILDING - HURON, S.D. MAX CURRENT $=659$ MIN CURRENT = EXTERIOR TEMP. $=10.2 \mathrm{C}$ WIND SPEED $=1.5 \mathrm{M} / \mathrm{S}$ $+1-.6 \mathrm{C} \quad+1-.9 \mathrm{M} / \mathrm{S}$

\section{INTERIOR TEMPERATURES}

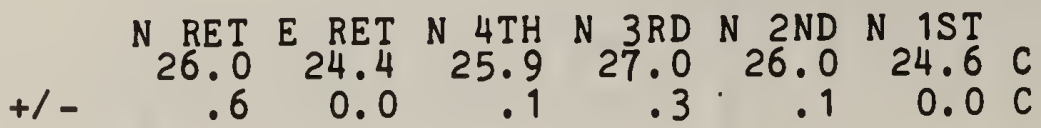

$$
\begin{array}{ccc}
\text { HVAC FAN OPER } & \text { FNE } 1 & \text { ZONE } 2 \\
594 & 595 & \text { SEC }
\end{array}
$$

TRACER CONCENTRATIONS

$N$ RET E RET N 4TH N 3RD N 2ND N 1ST

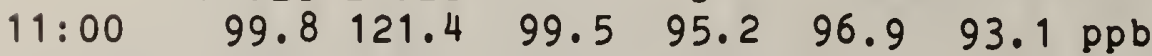

$\begin{array}{llllllll}11: 10 & 89.8 & 88.8 & 89.9 & 87.9 & 86.0 & 86.9 & \mathrm{ppb}\end{array}$

$\begin{array}{llllllll}11: 20 & 82.7 & 77.6 & 83.5 & 84.8 & 82.9 & 84.4 & \mathrm{ppb}\end{array}$

$\begin{array}{llllllll}11: 30 & 82.1 & 76.1 & 82.1 & 81.3 & 82.4 & 81.6 & \mathrm{ppb} \\ 11: 40 & 78.6 & 75.1 & 81.4 & 80.9 & 80.8 & 78.3 & \mathrm{ppb}\end{array}$

$\begin{array}{llllllllll}\text { INFIL } & .24 & .31 & .19 & .17 & .12 & .21 & / H R\end{array}$
611

$10 / 8 / 8211$

WIND DIR. $=135$. DEG. 
Table 7. Typical One-Hour Decay Tests for Columbia

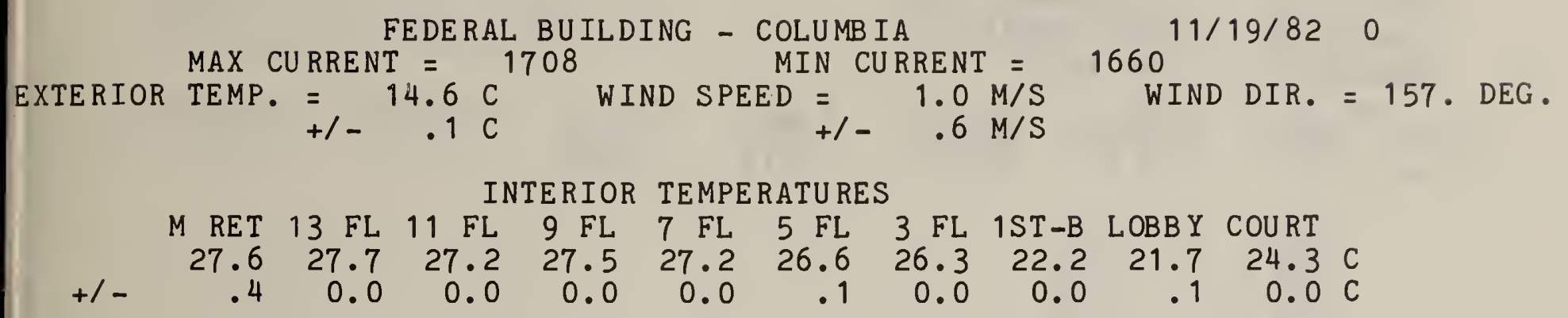

HVAC FAN OPERATION

$\begin{array}{rccc}\text { TOWER } & \text { 1ST-BAS } & \text { COURT } & \\ 0 & 0 & 0 & \text { SEC }\end{array}$

TRACER CONCENTRAT IONS

$0: 00$

$0: 10$

$0: 20$

$0: 30$

$0: 40$

$M$ RET $13 \mathrm{FL} 11 \mathrm{FL} 9 \mathrm{FL} 7 \mathrm{FL} 5 \mathrm{FL} 3 \mathrm{FL} 1 \mathrm{ST}-\mathrm{B}$ LOBBY COURT

$M$ RET $13 \mathrm{FL} 11 \mathrm{FL} 9 \mathrm{FL} 7 \mathrm{FL} 5 \mathrm{FL} 3 \mathrm{FL} 1 \mathrm{ST}-\mathrm{B}$ LOBBY COURT

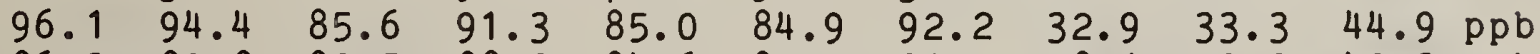

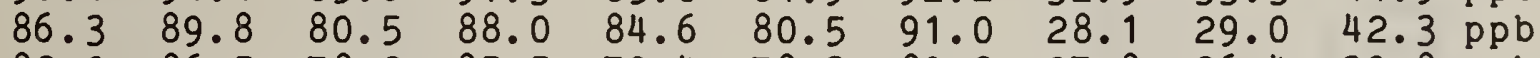

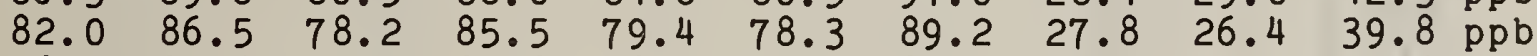

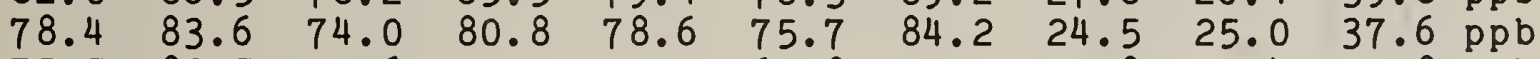

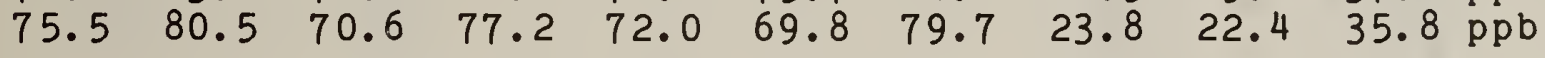

$\begin{array}{llllllllllll}\text { INFIL } & .27 & .22 & .27 & .27 & .30 & .28 & .27 & .37 & .50 & .34 & / \mathrm{HR}\end{array}$ 
Table 8. Data Files for Ann Arbor Building with No Outoide Air Intake CITY AND BUILDING : FEDERAL BUILDING - ANNARBOR

CONDITION : O\% OUTSIDE AIR

CONDITION : VENTS UNSEALED

CONDITION : WIND DATA

$\begin{array}{rlr}\text { DATE } & \text { HOUR } & \text { W.SPEED } \\ \text { 2/ } 4 / 83 & 18 & \\ \text { HVAC } & = & .47 \\ \text { 4THF } & =.71 \\ \text { 3RD F } & =.39 \\ \text { 1\&2 F } & =.57 \\ \text { LOB. } & =.76 \\ \text { P.O. } & =2.28\end{array}$

DATE HOUR W.SPEED

$\begin{array}{rl}4 / 83 \quad 19 & 1.1 \\ \text { HVAC } & =1.24\end{array}$

$4 T H F=1.01$

$3 R D=.54$

$1 \& 2 \mathrm{~F}=.52$

LOB. $=.97$

P.O. $=1.43$

DATE HOUR W.SPEED

2) $4 / 8320 \quad 1.0$

HVAC $=.62$
4THF $=.42$
3 RD F $=.62$
1\&2 F $=.58$
LOB. $=1.22$
P.O. $=1.37$

DATE HOUR W.SPEED

2/ $4 / 83 \quad 21 \quad 1.0$

W. DIR

270.0

T. OUT

.8

T. IN

22.9

T. DIFF

21.5

AI. AVE

.86

1.4

W. DIR
270.0

T. OUT

T. IN

22.7

T. DIFF

AI. AVE

20.9

.95

T. IN
22.5

T. DIFF

AI. AVE

1.5

21.0

.81

HV AC $=.54$
3RD F $=.64$
1\&2 F $=.66$
LOB. $=1.53$
P.O. $=1.26$

DATE HOUR W.SPEED

2) $4 / 83 \quad 22 \quad .8$

W.DIR T.OUT

270.0

$\mathrm{HVAC}=.61$

$4 \mathrm{THF}=.57$

$3 R D F=.64$

$1 \& 2 \mathrm{~F}=.62$

$\mathrm{LOB} .=1.27$

P.O. $=1.23$ 
Table 9. Data Files for Ann Arbor Building with Outside Air Intake CITY AND BUILDING : FEDERAL BUILDING - ANN ARBOR

CONDITION : AIR INTAKE

CONDITION : VENTS UNSEALED

CONDITION : WIND DATA

$\begin{array}{ccc}\text { DATE } & \text { HOUR } & \text { W.SPEED } \\ 5 / 25 / 83 & 8 & 1.8 \\ \text { HVAC } & =3.19 \\ \text { 4TH F } & =3.90 \\ \text { 3RD F } & =3.38 \\ \text { 2ND F } & =3.98 \\ \text { IST F } & =2.94 \\ \text { LOB . } & =1.90\end{array}$

$\begin{array}{rcc}\text { DATE } & \text { HOUR } & \text { W.SPEED } \\ 5 / 25 / 83 & 9 & 1.5 \\ \text { HVAC } & =2.51 \\ 4 \text { TH F } & =1.82 \\ 3 \mathrm{RD} F & =2.58 \\ \text { 2ND F } & =2.51 \\ \text { 1ST F } & =1.25 \\ \text { LOB. } & =1.97\end{array}$

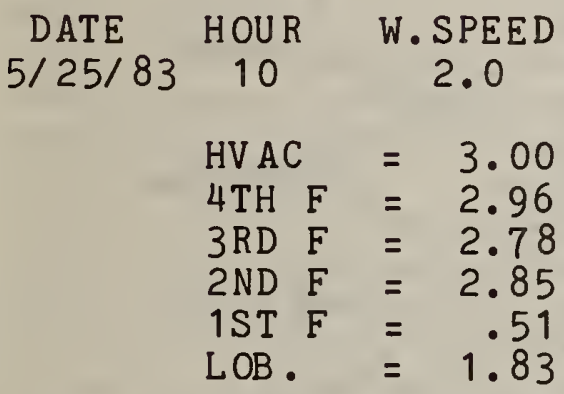

$\begin{array}{cccccccc}\text { DATE } & \text { HOUR } & \text { W.SPEED } & \text { W.DIR } & \text { T.OUT } & \text { T.IN } & \text { T.DIFF } & \text { AI.AVE } \\ 5 / 25 / 83 & 11 & 1.9 & 270.0 & 13.8 & 23.6 & 9.8 & 2.58\end{array}$

$\mathrm{HVAC}=3.24$

$4 \mathrm{THF}=2.52$

$3 R D=3.00$

2NDF $=2.71$

$1 \mathrm{ST} F=1.86$

LOB . $=2.17$

$\begin{array}{lll}\text { DATE HOUR W.SPEED } & \text { W.DIR } \\ \text { HVAC } & =2.51 \\ \text { 4THF } & =1.82 \\ \text { 3RD F } & =2.58 \\ \text { 2ND F } & =2.51 \\ \text { 1ST F } & =1.25 \\ \text { LOB } & =1.97\end{array}$

DATE HOUR W.SPEED

$5 / 25 / 83 \quad 12$

1.9

W. DIR

270.0

T. OU T

14.2

T. IN

23.5

T. DIFF

9.3

AI. AVE

2.73

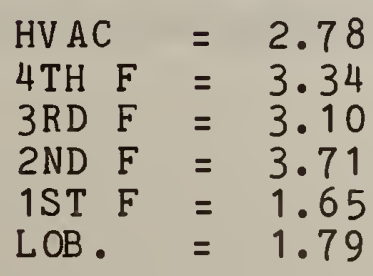




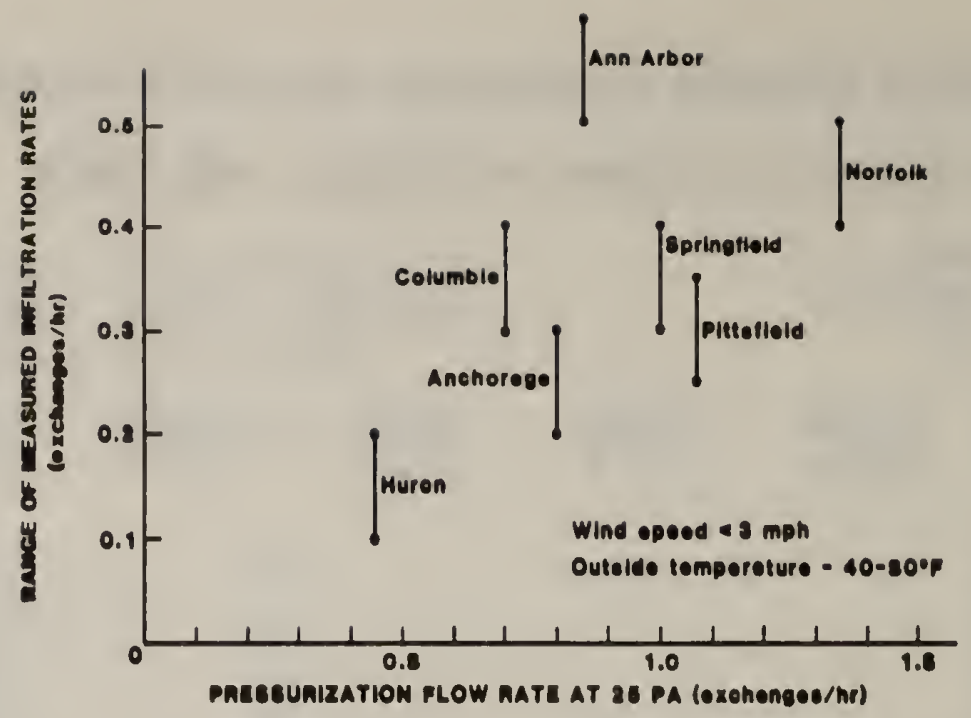

Figure 10. Natural Air Infiltration Rates Versus Induced Air Exchange Rates at $25 \mathrm{~Pa}$

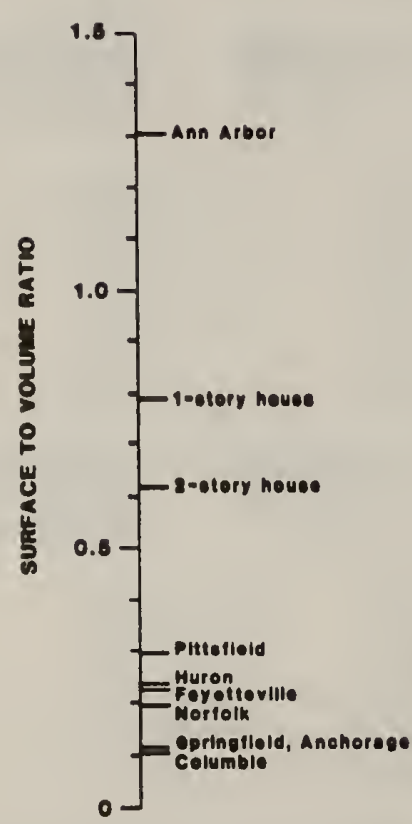

Figure 11. Distribution of Surface to Volume Ratio Among Federal Buildings and Residences

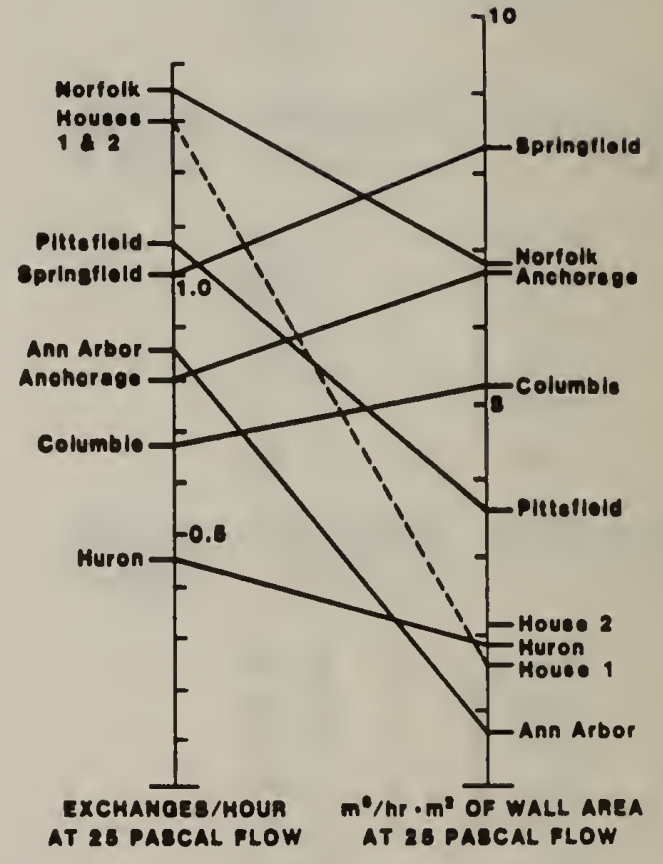

Figure 12. Comparison of Ranks of Pressurization Test Results 


\subsection{Background}

Thermographic inspection by use of infrared (IR) imaging systems is a diagnostic tool to locate thermal defects in a building envelope. IR thermography is a technique using non-contact scanning devices to convert the IR radiation from the object surface to visible light by providing the image of the surface intensity variation. The application of IR thermographic surveys to detect thermal anomalies and to determine insulation effectiveness in large buildings permits the selection of retrofit actions to be carried out to achieve energy conservation. During field measurements, IR thermographic inspections are usually carried out both internally and externally under suitable weather conditions. Thermographic data can be collected by photographing the thermal image display of the thermographic sensing system or by recording the video output of the system directly for subsequent reproduction. Information such as the temperature range of the sensing system and the environmental conditions during inspection are also required to accompany the thermographic data. A copy of such a thermal image, which corresponds to the apparent radiance temperature distribution along the surface, is called a thermogram. A typical thermogram of a surface will provide an intensity-modulated image where the bright and dark portions represent the hot and cold regions, respectively, and the grey shades show the intermediate range. Accordingly, the thermal integrity of the buildings can be analyzed and interpreted from the thermograms and the documentation.

\subsection{Summary of Results}

Thermographic surveys were conducted during the heating season of 1982-83 at all eight federal buildings. Since these are all large buildings, they were inspected thoroughly by exterior surveys with interior surveys at some regions where thermal anomalies were detected or suspected by outside inspections. A summary of thermal deficiencies interpreted from the thermographic inspection for all eight buildings is given in table 10 . Note that the numerical calculations of the total wall area and percentage of wall area subject to thermal defects in table 10 exclude the glass and window areas of the outside surfaces. As indicated in table 10 , the most severe thermal defects that occur in these buildings, besides defects in insulation, are air leakage through joints (wal1to-wall, ceiling-to-wall, and floor-to-wall) and window seals. Other common heat loss locations observed include shrinkage of insulation, and air penetration paths in walls and ceilings. The percentage of wall area subject to thermal defects in these buildings was found to be between 6 and 18 percent, also given in table 10. Descriptions of the thermal integrity and examples of defects observed in the thermograms are included in the following discussion. 
Table 10. Thermal Deficiencies Observed in Each Test Building

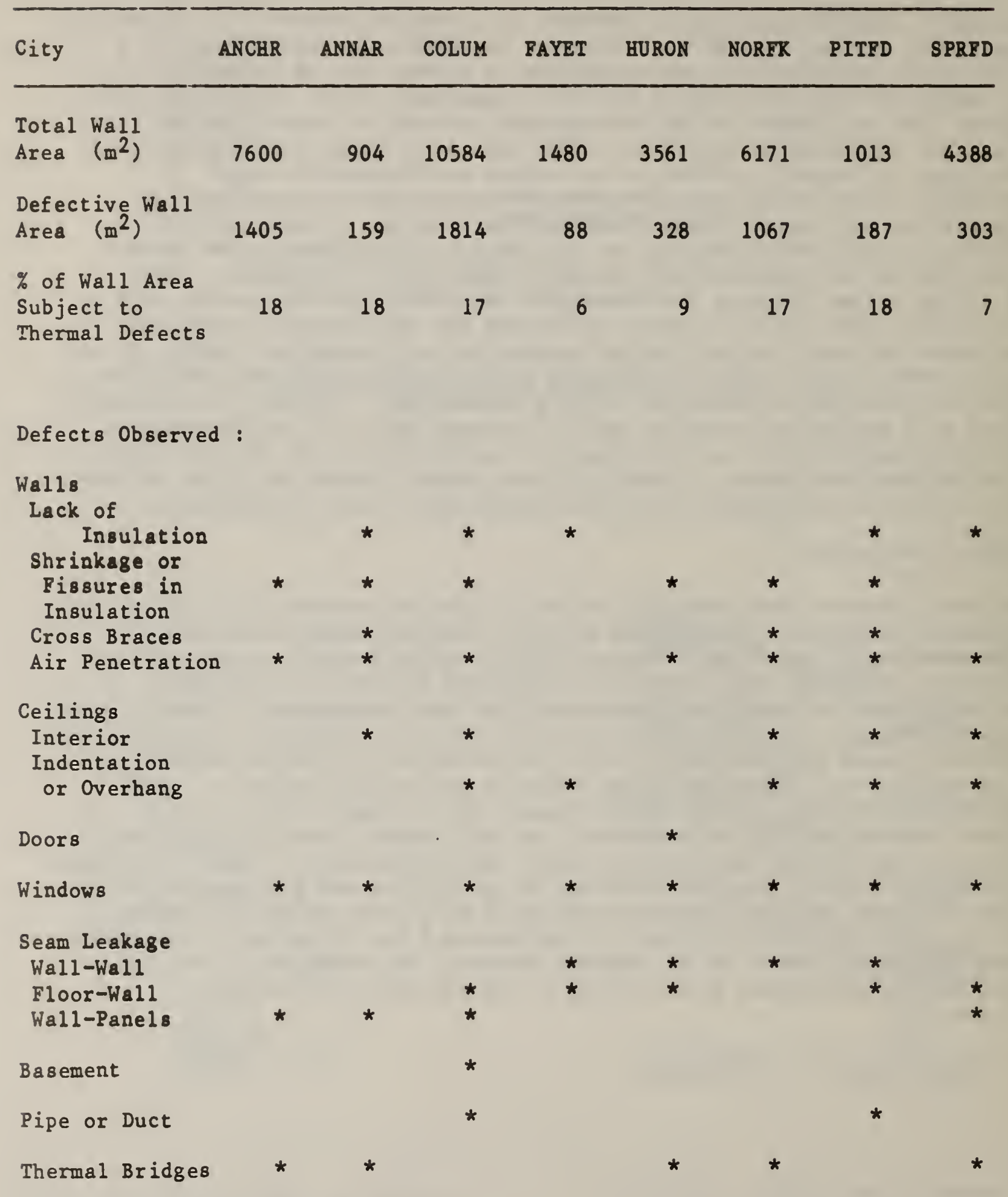


Description of Thermal Defects in the Anchorage Federal Building

The Federal Building in Anchorage, AK, is rather uniform in its thermal anomalies, for the defects in the modules are consistant and regular and the modules are nearly identical to one another, discounting the differences in the number of floors. The major defects are the thermal bridging at the panel supports and the leakage that occurs at the seams of the interlocking panels, especially at the corners and along the edges of the adjoining mirror walls, as illustrated in the thermograms from figures 13-1, 13-2, and 13-3. The mirror walls in figure 13-1 appear with bands of light and dark as the light bands have one-way mirrors for the floors inside and the dark bands have walls behind them. The high rating, $18 \%$, of wall area exposed to thermal defects is primarily due to this corner leakage and thermal bridging at the structural supports of the panels. Examples are the SW corner of the A module in figure 13-2 and the vertical seams in figures $13-3$ and 13-4. (The bright spot in the center of figure $13-3$ is the heat from a streetlight.) There also is extensive heat loss from the first floor windows that are on every module as illustrated by the west face of the A module in figure 13-4. 
Figure 13. Thermal Defect Observed in the Aachorage Bullding

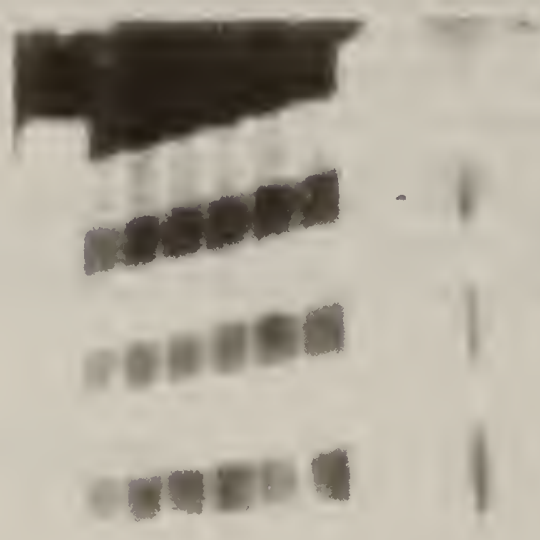

13-1

Mirror wall section

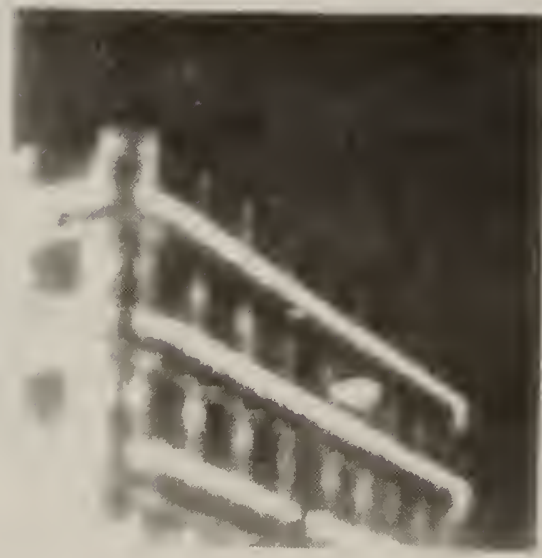

13-3

SE corner with E wall, upper floor $F$ module

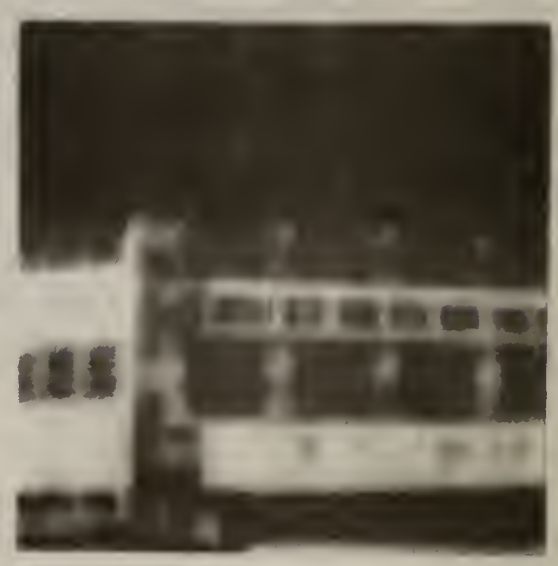

$$
\text { 13-2 }
$$

SW corner of A module

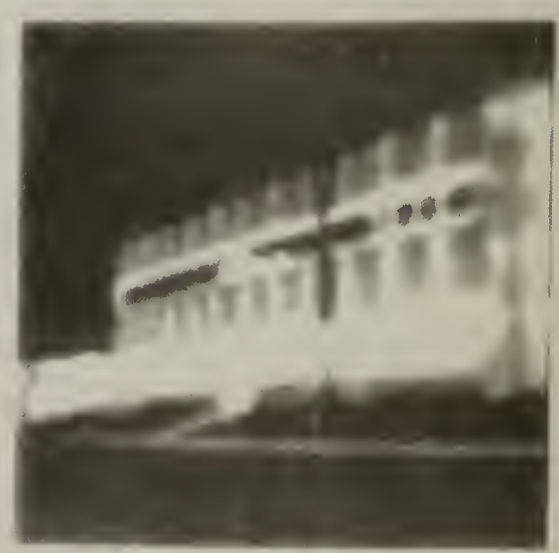

$13-4$

West face of the

A module 
The Federal Building in Ann Arbor has many types of thermal anomalies, but the predominant defect is the lack of insulation in large rectangular sections in the east and west walls. Note the large heat 1088 areas in figures 14-2, 14-4, and 14-5. There are similar voids in the insulation in the wall outcroppings that face east in the top center of the building as seen in figure 14-6. Leakage in the seams is also a distinct problem in the building, as the heat loss is evident in the thermograms of the adjoining panels in figures $14-1$ and $14-2$. The floorto-floor joints are sources of heat 1088 as well and are found in nearly all exterior wall areas. The strong flaring in the close-up of the east wall at the south end, as shown in figure 14-3, is indicative of serious thermal defects due to air leakage in the top seams. Note the cross-brace in the thermogram of the Post office in figure $14-5$ and some incompletely or unevely insulated walls in figures $14-2$ and $14-6$ which the irregular voids indicate. 
Figure 14. Thermal Defects Observed in the Ann Arbor Building

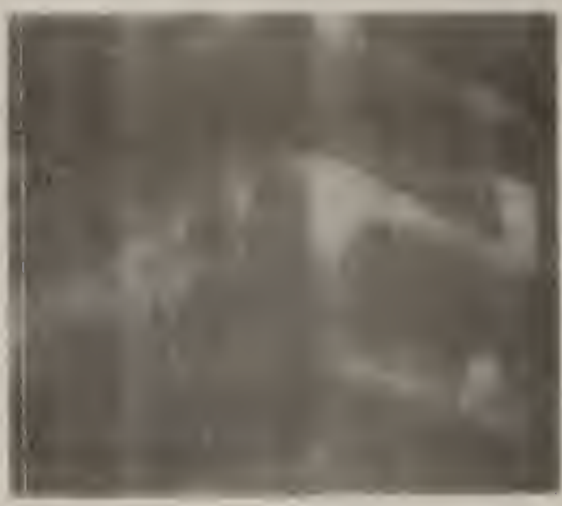

14-1

Middle two floors of SW corner

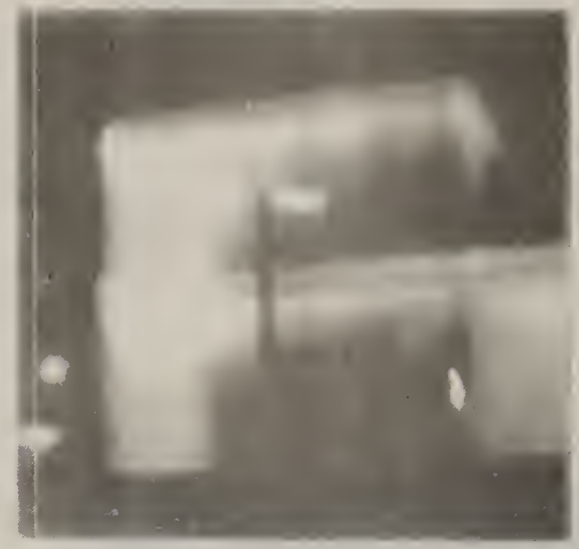

14-3

$E$ wall at the

$S$ end

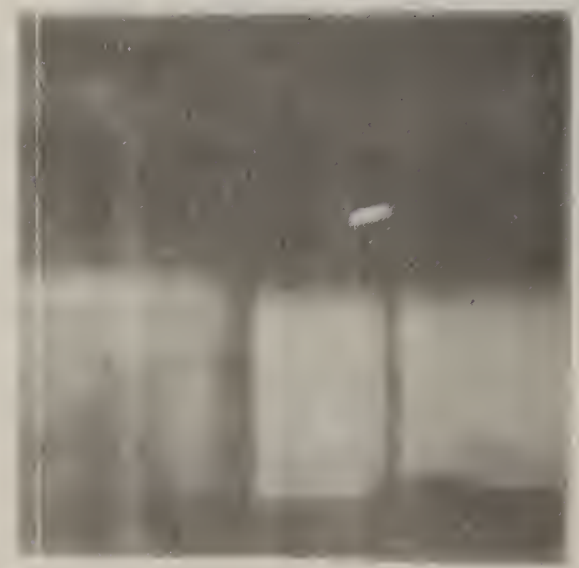

14-5

$E$ wall at the $N$ end, first floor

Post Office

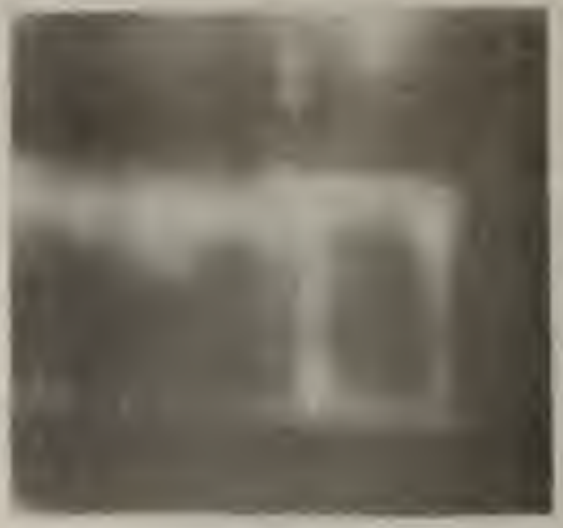

14-2

Top floors of the $W$ wall at the $S$ end

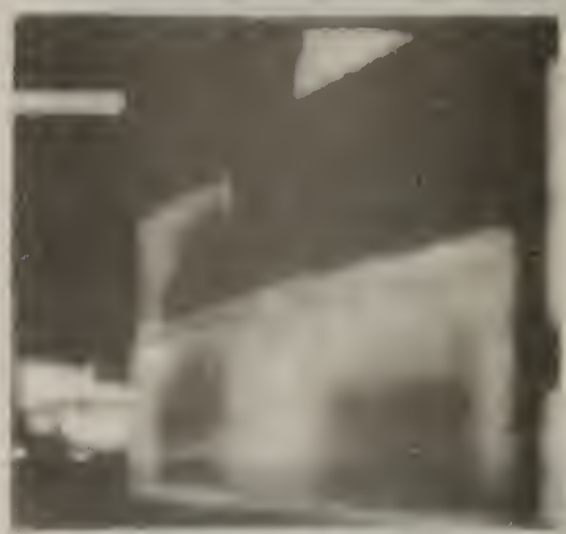

14-4

E wall at the

$S$ end

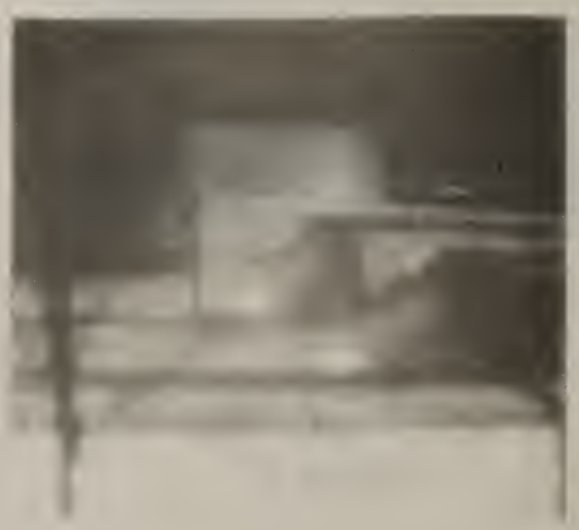

14-6

N face above and to the left of the front entrance 
The thermal anomalies observed in the Federal Building in Columbia, SC, consist primarily of leakage through defects in the window panels and voids in the insulation at the panel seams. The thermograms shown in figures 15-1 and 15-2 made by interior inspections illustrate some of the thermal defects, such as poor insulation, missing insulation, and compression of insulation around the window areas of this building. Figures $15-3$ and $15-4$ indicate the compression and voids in the insulation in the north wall of the fourth floor by interior and exterior thermograms, respectively. Similar defects over the entire building are the main contributors to the high percentage, $17 \%$, of wall area subjected to thermal anomalies. Note the seam leakage in the panels that make up the solid edges in figure 15-4. The heat $108 \mathrm{~s}$ depicted in figure 15-5 which rises up the west edge of the south wall and across the top edge of the building is due to the perimeter zone HVAC system ducts. The thermal integrity of the courthouse adjacent to the tower is also imperfect. Figure 15-6 shows the leakage that occurs at the NW corner indent of the courthouse, which is typical of the leakage at those seams. 
Figure 15. Thermal Defects Observed in the Col twa Building

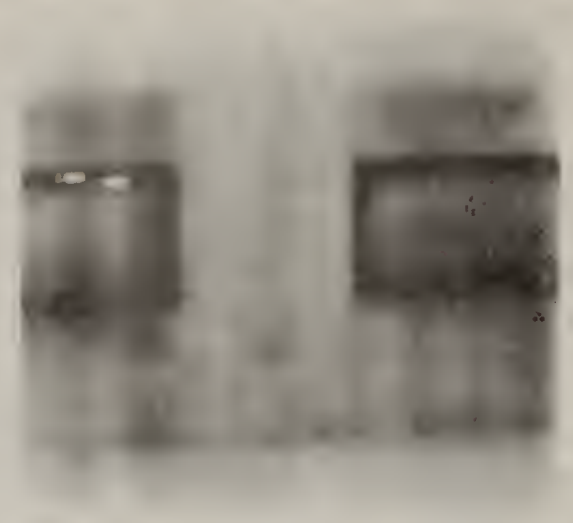

\section{5-1}

$N$ wall on the fourth

floor of the tower

(interior)

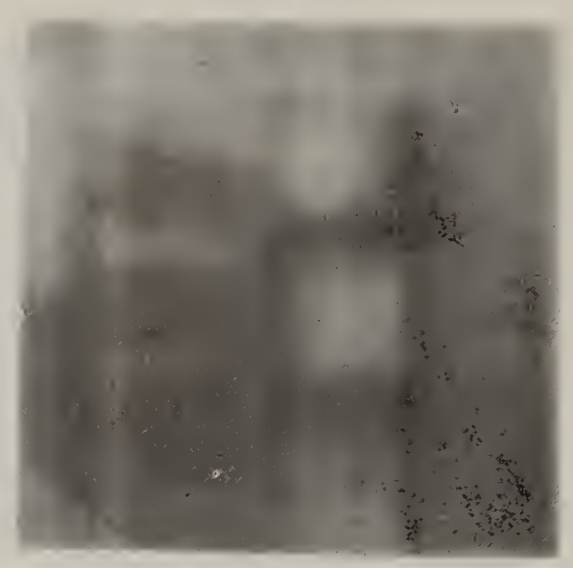

15-3

SE corner of the

fourth floor

of the tower (int)

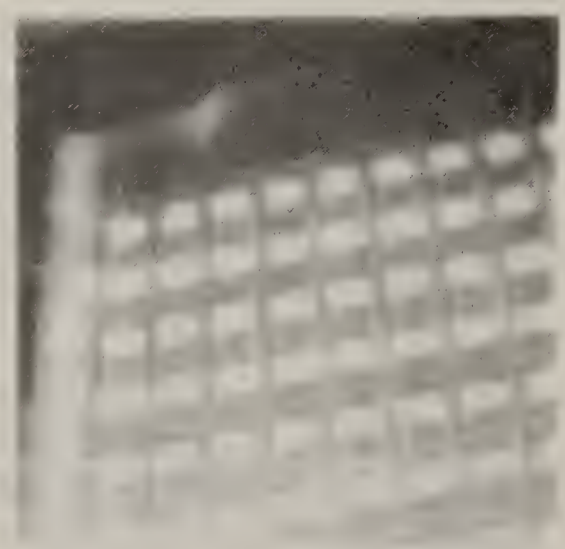

15-5

$S$ face with $W$ end

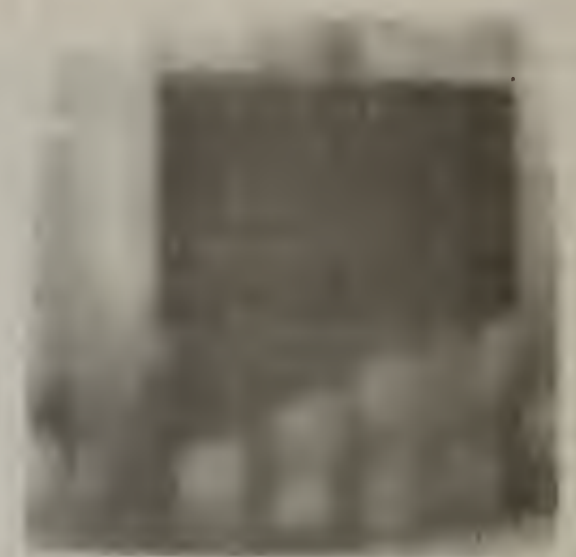

15-2

$\mathrm{N}$ wall on the fourth floor of the tower (interior)

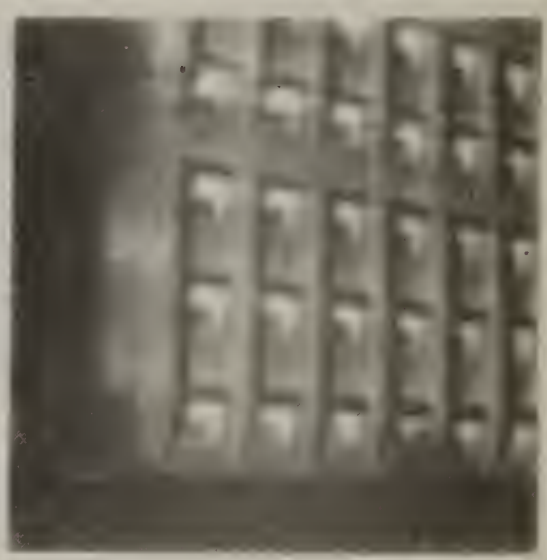

$15-4$

Lower west face of the tower at the $\mathrm{N}$ end

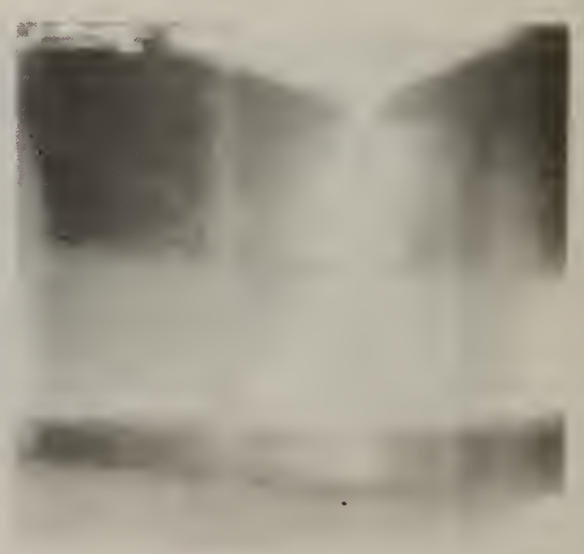

$$
15-6
$$

NW corner indent of the courthouse 
Of all the Federal Buildings inspected, the wall areas of the Fayetteville Building are observed to be relatively uniformly insulated, however this is actually due to a lack of insulation in the exterior wall envelope. This indicates the limitation placed on infrared methods when applied to uninsulated walls. The leakage of the floor-to-floor seams are the prominent defects. Examples are the seams of the elevator towers as shown in figures 16-1 and 16-3. This type of thermal defect is also evident in the east and west walls below the overhangs where the roof of the overhanging section appears to be a source of heat loss as seen by the flaring against the tower in figure 16-1. Note that the heat loss through the floor of the overhangs could be due to the corner seams, for the defect is well-defined along the edges of the overhanging floor. There are relatively few insulation voids which helps account for the 10 w $6 \%$ thermal defects of the total wall area. 
Figure 16. Thermal Defects Observed in the Fayetteville Building

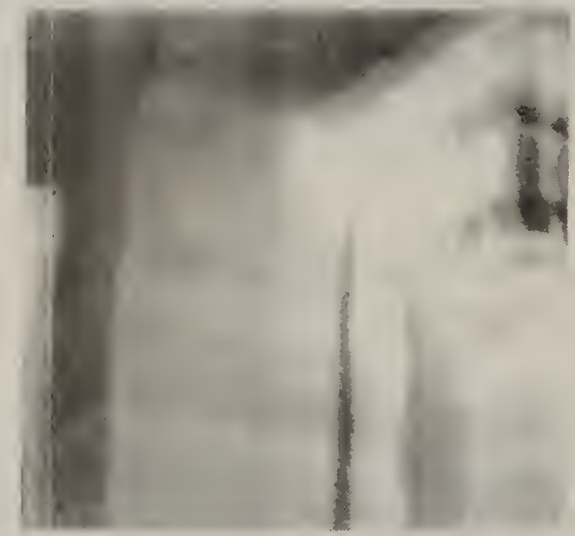

16-1

NE corner with one east face tower

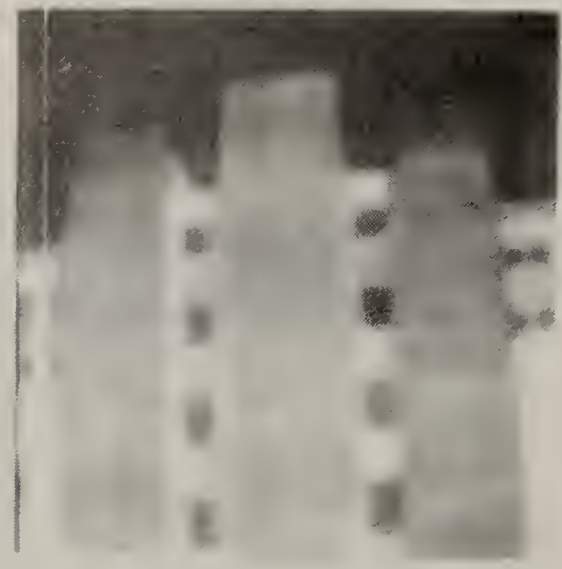

16-3

$E$ end with three

elevator towers

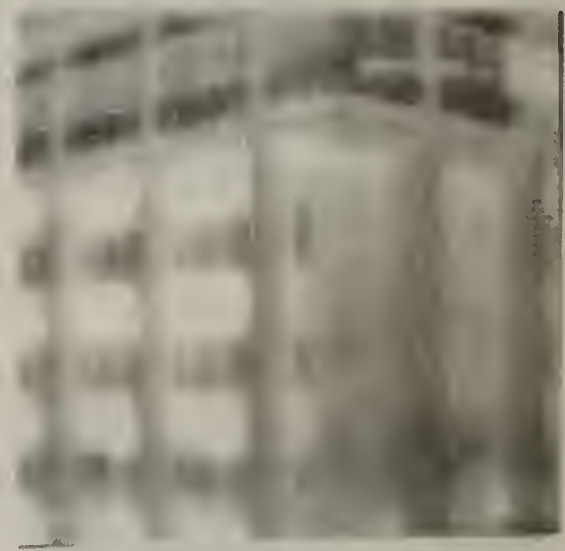

16-2

NW corner with west wall under overhang

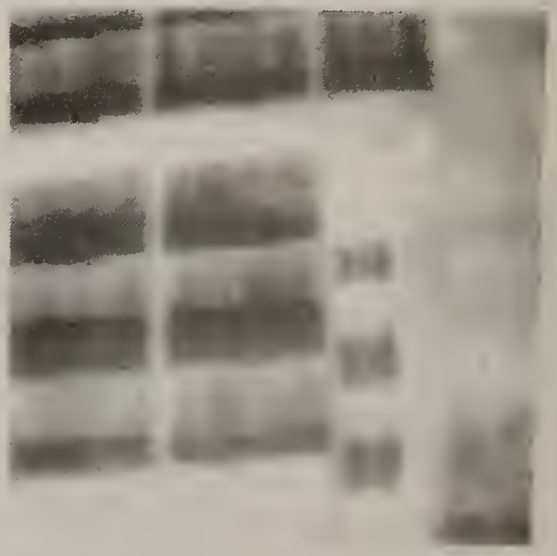

$16-4$

NW corner above $N$ entrance with view up to overhang 
Description of Thermal Defects Observed in the Huron Federal Building

The Federal Building in Huron, SD, is relatively sound with respect to thermal integrity. The $9 \%$ thermal defects in wall area is primarily due to leakage through seams between floors and thermal bridges at intersections of walls, floors, and beams, as seen in figure 17-3. There is also an amount of flaring around and above the windows as shown in figures 17-1 and 17-3. Note how the seams appear to be more defective as they approach the windows, especially as seen in figure 17-3. The brightness in the leftmost side of figure 17-2 is due to the windows near the front entrance in the background. Figure 17-4 is an interior thermogram of the fourth floor indicating a beam which conducts cold air in on the right hand side. Figure 17-4 also depicts some shrinkage in the insulation in the third and fifth sections of the wall, as well as air leakage at the top and the bottom of the wall where it intersects the floor and ceiling. 
Figure 17. Thermal Defects Observed in the Huron Building

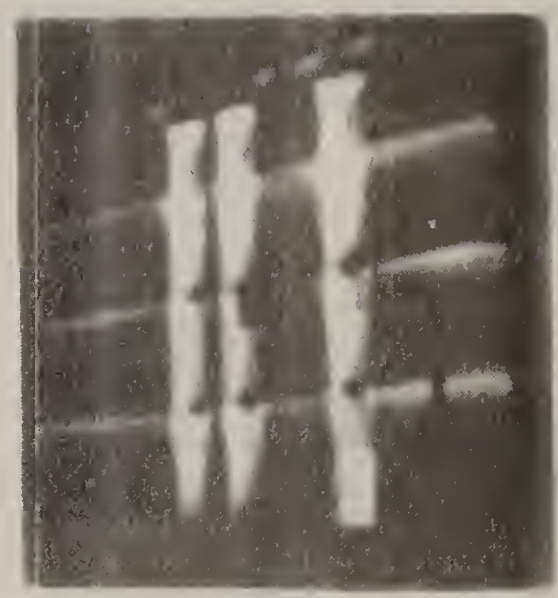

17-1

E wall with $N E$ entrance off to right

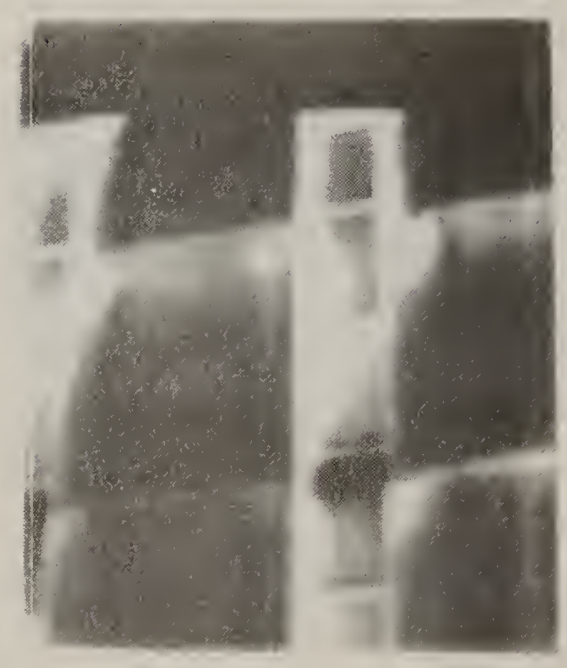

$$
17-3
$$

Close-up of middle section on $E$ wall as shown in 5-2

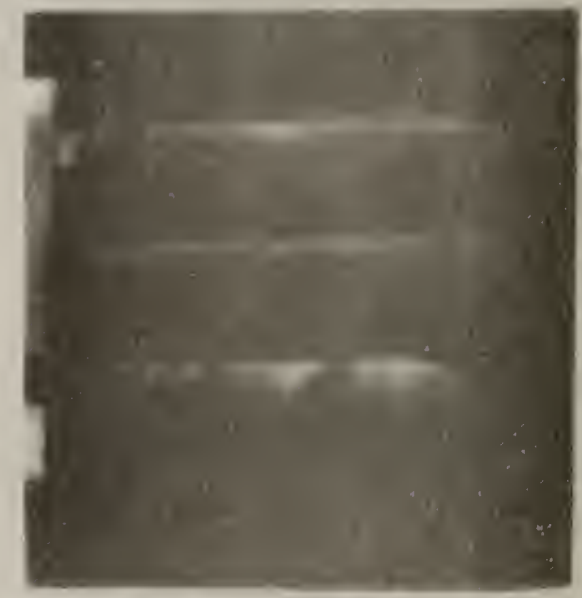

$$
17-2
$$

$N$ face with $\mathrm{NE}$ entrance on left

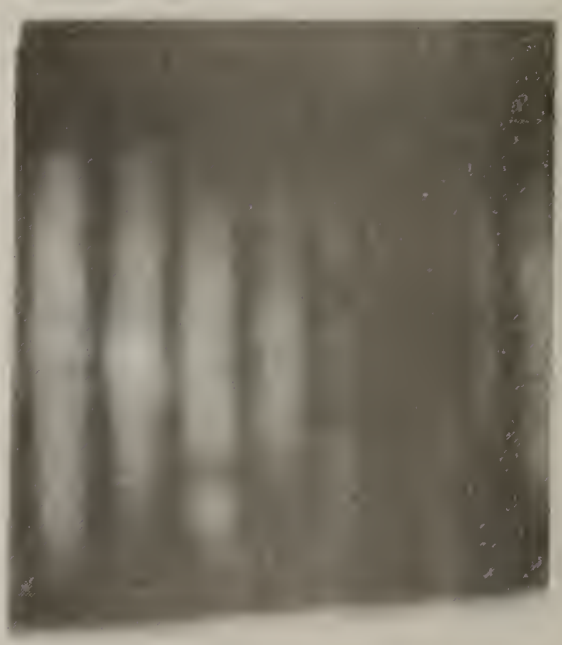

$$
17-4
$$

Fourth floor interior N wall of the E wing 
The thermal anomalies observed in the Federal Building in Norfolk, VA, consisted of two basic kinds, the leakage that occurred at the wall-to-floor seams and the leakage at the exterior panel seams. In figure 18-1, there is a great deal of heat loss shown at the panel seams in the middle of the east wall. The wal1-topost-to-floor seams are also sources of heat loss as illustrated in figures 18-2 through 18-5. Figure 18-2 shows an interior thermogram of the west wall at the south end. (The middle window does not have the blind pulled down and is not reflecting.) Note the vertical darker area in the center of the picture, which is a beam conducting cold inwards. Figures 18-3, 18-4, and 18-5 show leakage between the windows and from the panel seams in the solid wall sections below, which correspond to the horizontal, long, bright white areas across the entire length of the building. Other thermal defects observed include the floors of the third floor and second floor overhangs, as evidence of voids in insulation and leakage at the seams is identified in figures $18-5$ and $18-6$. 
Figure 18. Thermal Defects Observed in the Norfolk Building

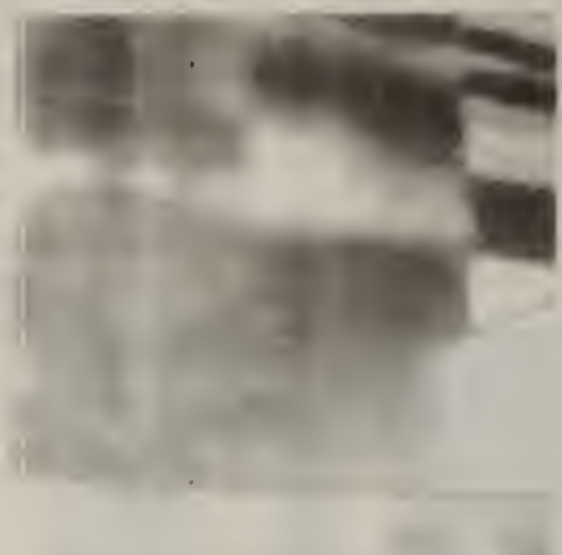

18-1

Lower wall section of $\mathrm{E}$ พal1

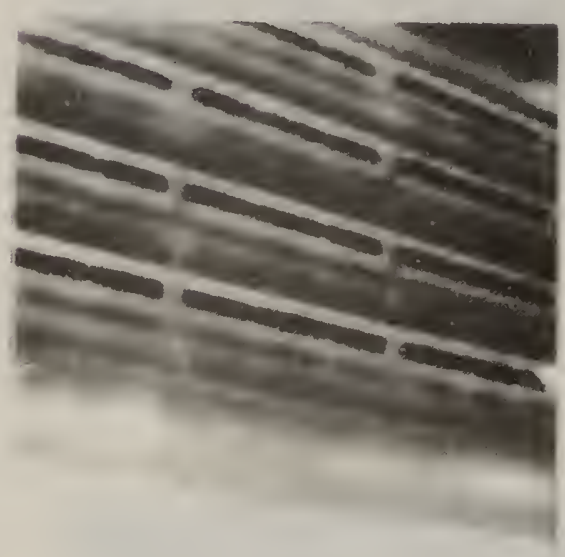

18-3

$W$ face at the $N$ end

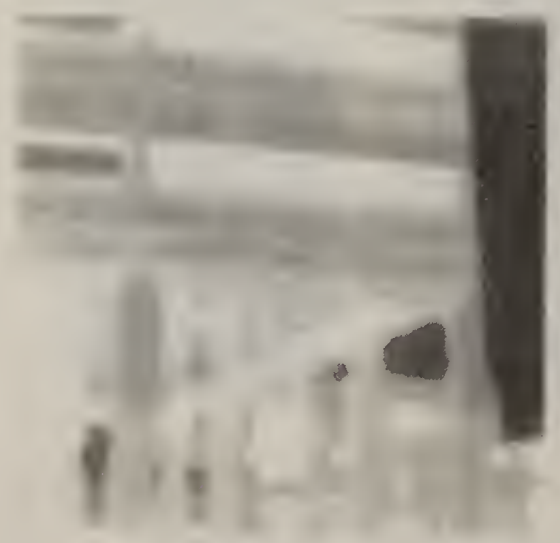

$18-5$

Third floor overhang of the $N$ wall at the $W$ end

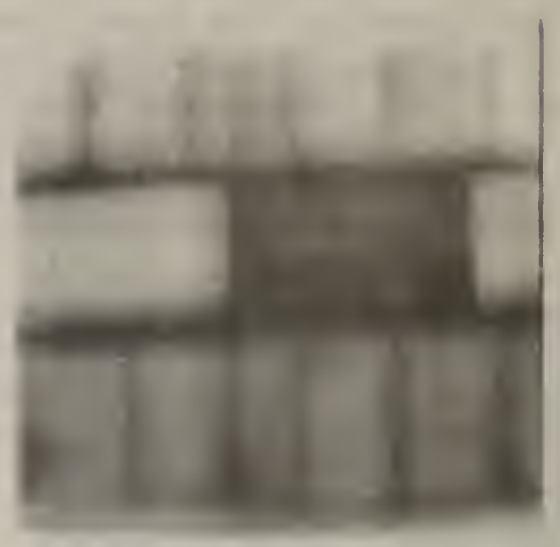

18-2

$W$ wall at $S$ end on the third floor

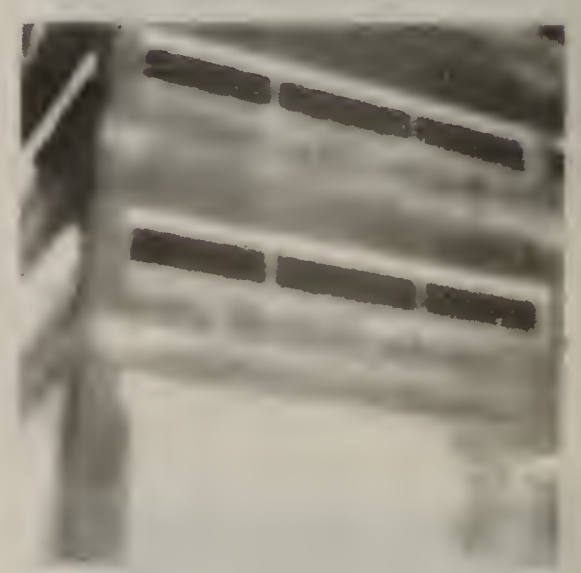

18-4

E wall at the SE corner

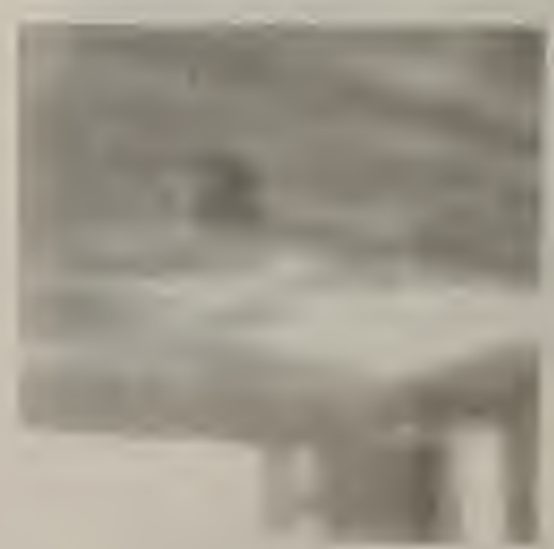

18-6

NE overhang of second floor over garage 
The thermal integrity of the Federal Building in Pittsfield, MA, can be characterized by a large number of markedly undefined voids in the insulation. Many sections have insulation that is distributed unevenly, and there are areas where a whole section of wall is lacking insulation as shown in figure 19-2, where the top third of the wall next to the front entrance is distinctly warmer. The large percentage, $18 \%$, of defective wall observed in the Pittsfield Building is due to these large rectangular voids, but the problems with all types of seams must also be taken into consideration. In figure 19-1 for example, note the leakage from the seam below the second floor windows and the wal1-to-wall seam in the upper right-hand corner. The posts running through the walls also cause heat loss as shown in figures $19-4$ and 19-6. These two thermograms are characteristic of those for every wall-to-post seam in the building. At each corner there is an indentation in which there is leakage as illustrated by the thermograms in figures 19-3 and 19-4, where the exterior and the interior of the NW corner on the first floor are shown. The dark line in figure 19-4 indicating the penetration of cold corresponds to the bright white regions in figure 19-3 which indicate heat loss to the outside. Other defects observed in this building include the possibility of a damaged pipe inside the north wall as shown in figure 19-5, where a flaring warm area near the top is detected. 
Figure 19. Thermal Defects Observed in the Pittofield Building

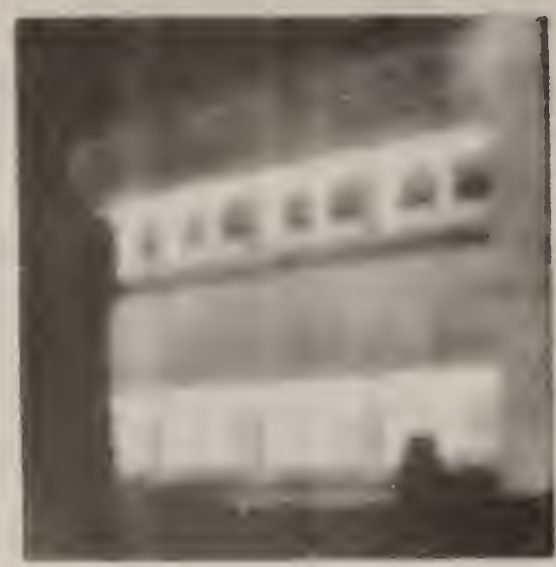

19-1

$S$ end of $E$ wall

(exterior)

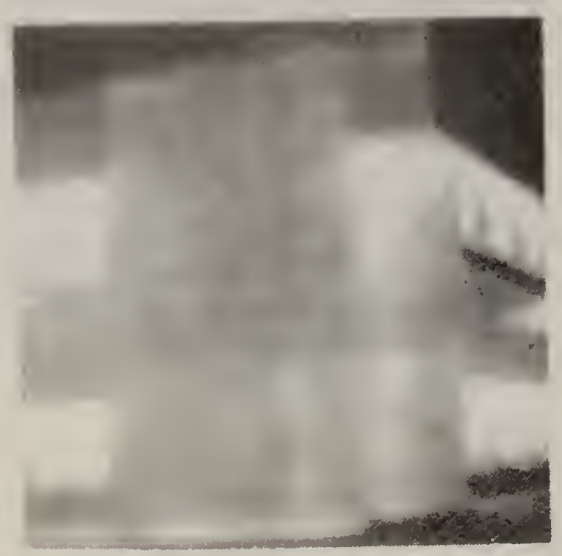

19-3

NW corner with $N$ wall section and indent (exterior)

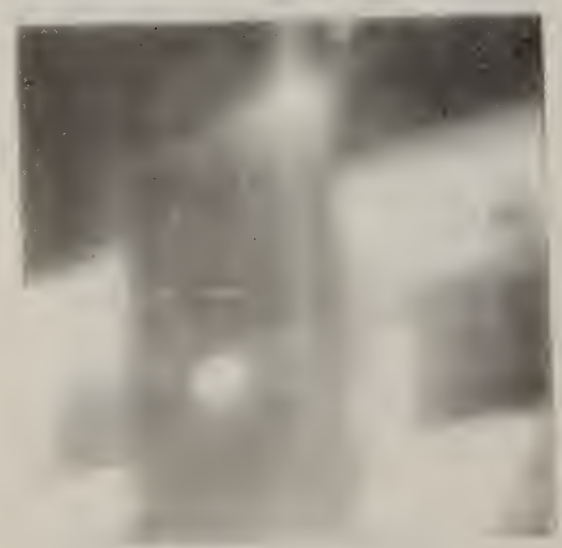

19-5

Center of $\mathrm{N}$ wall

(exterior)

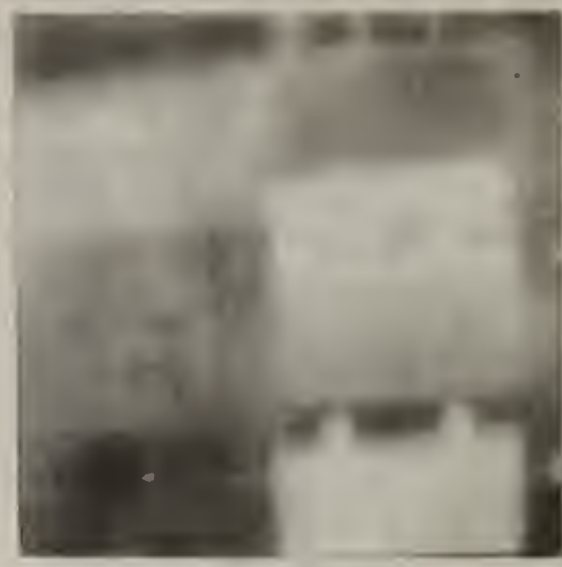

19-2

The front entrance on $\mathrm{E}$ wall (exterior)

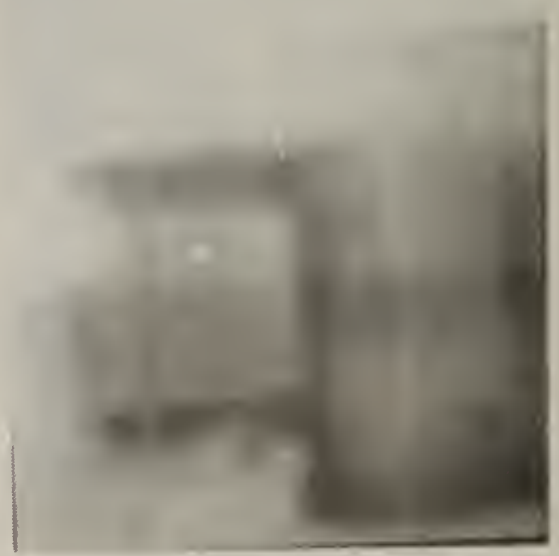

19-4

NW corner with W window and indent (interior)

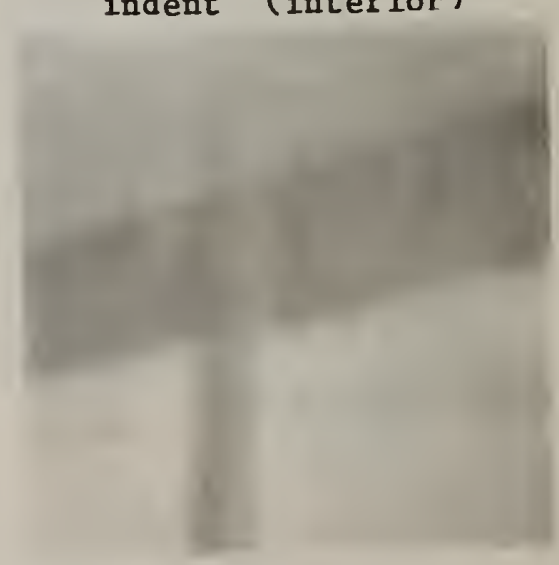

19-6

Wa11-post seams on $\mathrm{E}$ wall first floor 
Description of Thermal Defects in the Springfield Federal Building

The Springfield Federal Building has a relatively 1ow, 7\%, rating of wall area subject to thermal anomalies. The main defect is the post-to-wall joints as seen in figures 20-1 through 20-6. Note the consistant pattern of the defect in figures 20-1 and 20-3. An exterior close-up of the post-to-wall seam is shown in figure 20-2 at the SW corner with an interior view in figure 20-4. The dimensions of the columns are defined in figures 20-1 and 20-2 by the heat loss that occurs at the edges as the column rises up the side of the building. The interior view shows the cold penetrating to the interior at the sides of the pillar at a single floor. The heat loss from the joints is also consistently evident at the corners, where there are small insulation voids above the windows as well which can be observed in figure 20-3 and 20-5. There is also a great deal of heat loss from the glass windows on the first floor and from the atrium which rises up the center of the east face of the building, as shown in figures $20-5$ and $20-6$. 
Figure 20. Thermal Defects Observed in the Springfield Building

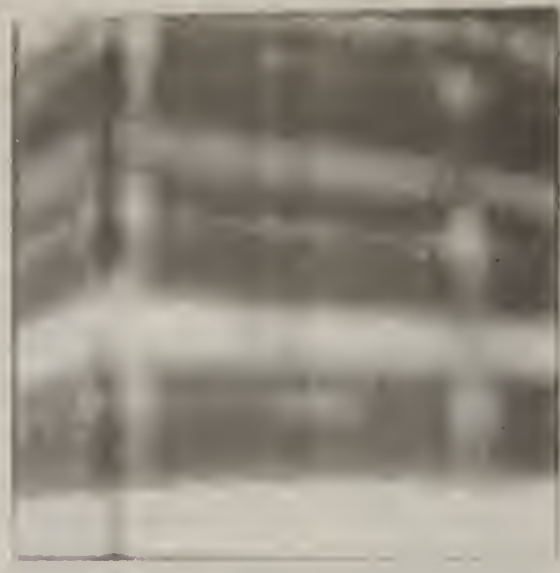

20-1

SE corner of

the $N$ wing

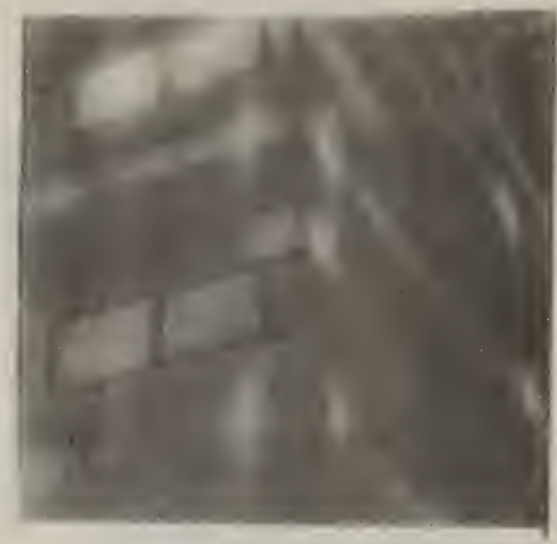

20-3

SW corner showing seams at the second and third floors

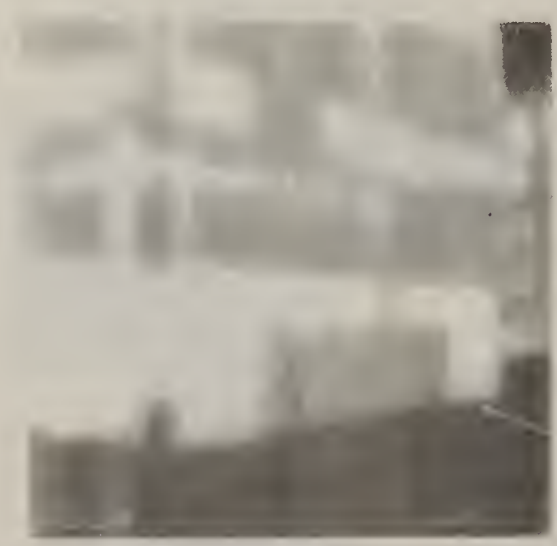

20-5

S wall first floor

glass wall with metal

panel, $W$ end

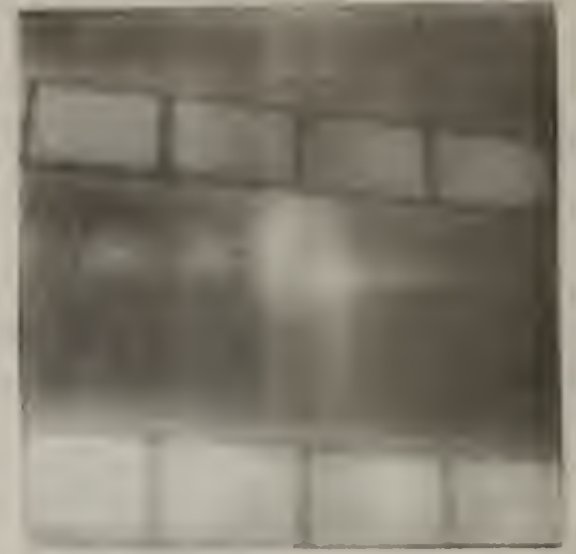

20-2

Close-up of the floor-wallpost seam on the $E$ face of the $N$ wing

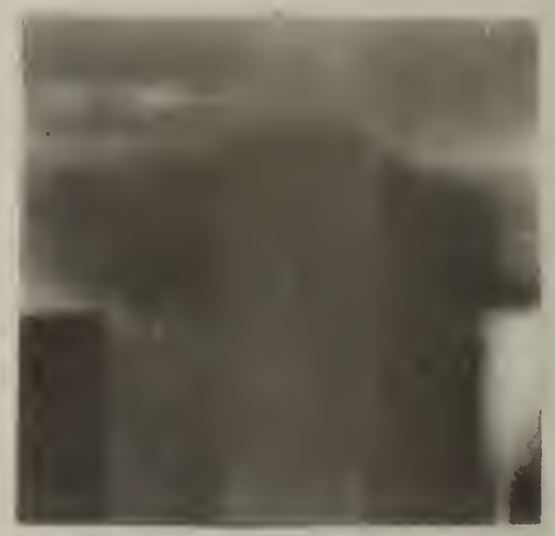

20-4

Interior thermogram of the wall-post seam

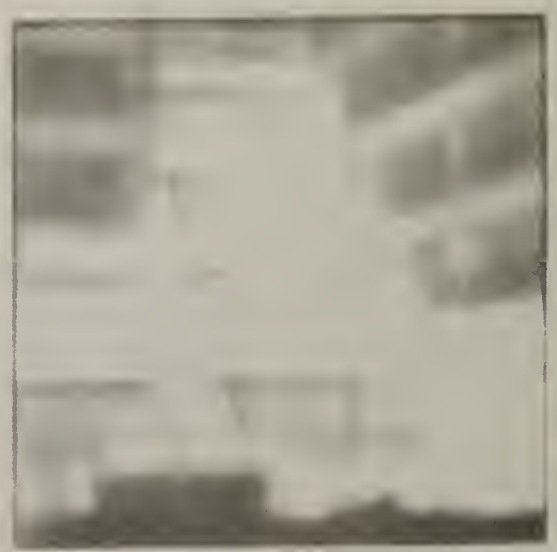

20-6

Atrium rising up center of $E$ face 
5. Determination of the Thermal Resistances of the Building Envelope Using Heat Flow Meters and a Portable Calorimeter

In an attempt to determine the feasibility of directly measuring the thermal resistance of sections of the building envelope, NBS deployed a micro-computer based data acquisition system which could monitor the output of heat flow meters, thermistors for measuring temperature, and the electrical energy used by a portable calorimeter. Two of these systems were used in the project.

The heat flux transducers used for measuring the rate of heat transfer through the building components included heat flow meters and a portable calorimeter. The heat flow meter was a $10 \mathrm{~cm}$ diameter circular, wafer-type sensor with the hot and cold junctions of an embedded thermopile attached to its surfaces. The heat flow meters were attatched with masking tape to the selected locations on the interior surfaces of the building components including the exterior walls and the roofs, structural beams and columns, and the floors. The voltage signals produced by the heat flow meter were proportional to the heat flow through the cicular disk. The temperatures of the outdoor air and indoor air in the vicinity of the heat flow meters were measured with thermistors. A portable calorimeter was designed, constructed, and used for on-site measurement of the rate of heat 1088 through the external wall of the selected buildings. The calorimeter consisted of a five-sided box having dimensions of $124 \mathrm{~cm}$ wide by $198 \mathrm{~cm}$ high by $20 \mathrm{~cm}$ deep which was fabricated from semi-rigid fiber glass insulation board. The calorimeter contained an electric heater, which was controlled automatically to maintain the air temperature inside the calorimeter box equal to that of the guard room. The heat flow through the metered area was measured by monitoring the total electrical power consumption of the heater. A watt-hour meter equipped with an optical electronic device, which generated a pulse for each 1.8 Wh of electricity consumed by the heater, was installed in the circuit to the heater. These pulses were totaled by an electronic counter. The outputs from the device in the modified watt-hour meter, the heat flow meters, and thermistors, were acquired every two seconds and processed, and the test data were recorded at one hour intervals on a floppy disk by the micro-computer.

Construction details of the typical exterior walls on which heat flow measurements were made are summarized in table 11. Table 12 presents the thermal resistance values measured with heat flow meters and the portable calorimeter on the exterior walls for the test buildings. The measured wall resistance value was the average of R-values calculated by dividing the average temperature difference between the inside and outside air present across the building wall, by the average heat flow rate over a period of 24 hours. The steady-state thermal resistances of these walls for the test buildings were computed using the series resistance method and published data on thermal properties of building materials. These predicted values are also presented in the table along with the corresponding measured indoor and outdoor air temperatures. The calibration of heat flow meters employed a standard guarded hot plate apparatus. The sensitivity of individual heat flow meters was determined by inserting them between the warm and cold plates maintained at constant temperatures and subjecting each meter to a unifrom heat flux at the mean temperatures experienced during the tests. Also shown in the table are the significantly high wall resistance measured by the calorimeter for the building in Columbia, SC, which may have resulted from additional heat laterally conducting into the measuring area from a nearby hot air duct. 


\section{Building Location}

Ann Arbor, Michigan

Columbia, S. Carolina

Springfield, Massachusetts

Huron,

S. Dakota

Norfolk, Virginia

Pittsfield, Massachusetts Anchorage, Alaska

Fayetteville, Arkansas

\section{Wa11 Description}

$1.3 \mathrm{~cm}(0.5$ in.) Quarry tile, $2.5 \mathrm{~cm}$ ( 1 in.) metal lath and motar bed, $25.4 \mathrm{~cm}$ (10 in.) concrete masonary unit, $3.8 \mathrm{~cm}$ ( 1.5 in.) semi-rigid glass fiber insulation board and $1.3 \mathrm{~cm}$ ( 0.5 in.) acoustic wall panel

$5.1 \mathrm{~cm}$ (2 in.) granite siding, $22.9 \mathrm{~cm}$ (9 in.) concrete, 5.1 $\mathrm{cm}$ ( 2 in.) glass fiber blanket insulation, and $1.6 \mathrm{~cm}(0.625$ in.) gypsum wallboard

$14.0 \mathrm{~cm}$ (5.5 in.) precast concrete panel, $6.4 \mathrm{~cm}(2.5 \mathrm{in.})$ semi-rigid glass fiber insulation board, and $1.3 \mathrm{~cm}(0.5 \mathrm{in.})$ gypsum wallboard on $9.2 \mathrm{~cm}$ ( $3.625 \mathrm{in.})$ metal studs

$10.2 \mathrm{~cm}$ (4 in.) face brick, $15.2 \mathrm{~cm}$ (6 in.) 1ight-weight concrete masonary unit, $7.6 \mathrm{~cm}$ ( 3 in.) semi-rigid glass fiber insulation board, and $1.6 \mathrm{~cm}(0.625 \mathrm{in.})$ gypsum wallboard

$10.2 \mathrm{~cm}$ (4 in.) face brick, $1.9 \mathrm{~cm}$ ( 0.75 in.) air space, 1.3 $\mathrm{cm}(0.5$ in.) gypsum board sheathing, $10.2 \mathrm{~cm}$ ( 4 in.) glass fiber blanket insulation, and $1.3 \mathrm{~cm}(0.5 \mathrm{in.})$ gypsum wallboard

$10.2 \mathrm{~cm}$ ( 4 in.) face brick, $5.1 \mathrm{~cm}$ ( 2 in.) semi- rigid glass fiber insulation board, and $10.2 \mathrm{~cm}$ ( 4 in.) brick

$12.7 \mathrm{~cm}$ ( 5 in.) precast concrete panel, $7.6 \mathrm{~cm}$ (3 in.) semirigid glass fiber insulation board, $10.2 \mathrm{~cm}$ ( 4 in.) glass fiber batt insulation, and $1.6 \mathrm{~cm}(0.625 \mathrm{in}$.) foil backed gypsum wallboard on $6.4 \mathrm{~cm}(2.5 \mathrm{in.})$ metal studs

$10.2 \mathrm{~cm}$ (4 in.) face brick and $30.5 \mathrm{~cm}$ (12 in.) concrete block 
Table 12. Comparsion of Wall Thermal Resistances Measured With a Portable Calorimeter and Heat Flow Meters to Corresponding Predicted Values

\author{
Building \\ Location

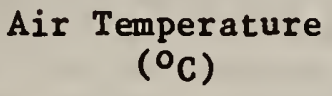

Air Temperature

$\left({ }^{\circ} \mathrm{C}\right)$

Wall Thermal Resistance

$$
\left(\mathrm{m}^{2}-{ }^{\circ} \mathrm{C} / \mathrm{W}\right)
$$

Measured Values

Calorimeter $\begin{array}{cc}\text { Heat Flow } \\ \text { Meter }\end{array} \begin{gathered}\text { Predicted } \\ \text { Value* }\end{gathered}$

Ann Arbor,

Michigan

20.1

4.1

1.95

2.03

1.87

Columbia,

S. Carolina

21.3

8.8

2.66

1.90

1.98

Springfield,

Massachusetts

20.8

5.5

1.20

2.22

2.29

Huron,

S. Dakota

19.4

3.3

2.11

3.60

2.97

Norfolk,

Virginia

25.1

9.1

1.46

2.76

Pittsfield,

Massachusetts

25.4

3.7

1.81

1.80

Anchorage,

Alaska

23.4

10.3

6.88

5.27

Fayetteville,

Arkansas

* Note: These values include air films with thermal resistances $0.12 \mathrm{~m}^{2}-{ }^{\circ} \mathrm{C} / \mathrm{W}$ at inside surface and $0.70 \mathrm{~m}^{2}-{ }^{\circ} \mathrm{C} / \mathrm{W}$ at the outside surface. This is based on an air velocity of $0.3 \mathrm{~m} / \mathrm{s}$ across the hot, and $0.2 \mathrm{~m} / \mathrm{s}$ for the cold side surfaces, respectively. 


\section{Conclusions}

This interim report has presented some preliminary findings of the building diagnostic tests of the eight GSA federal buildings. The air infiltration and pressurization measurements show that these buildings are not excessively leaky. In fact, they are tighter than most U.S. homes. The infrared inspections have located sites of air leakage and insulation defects in all the buildings. The percentage of wall area exhibiting thermal defects ranges from about 10 to $20 \%$ in the buildings. The U-value measurements show varying correlation with the calculated values. It is not clear whether any disagreement between these measurements and predictions arise from measurement techiques or predictive methods. Both estimates are based on assumptions of one-dimensional heat flow and this may not always be a good approximation. Further reports on this project will contain additional analysis of the infrared inspections and U-value measurements. Also, additional study of the air infiltration data, particularly weather dependence of infiltration, will be presented. 


\section{Acknowledgements}

The authors would like to thank David Eakins and Erma Striner of GSA for their continued support, assistance and encouragement. The technical contributions of Douglas Pruitt and Steve Schweinfurth's assistance in data analysis must also be noted. 


\section{REFERENCES}

1. Grot, R.A., Burch. D.M., Silberstein, S., and Galowin, L.S., "Measurement Methods for Evaluation of Thermal Integrity of Building Envelopes," NBSIR $82-2065,1982$.

2. Grot, R.A., Hunt, C.M., and Harrje, D.T., "Automated Air Infiltration Measurement in Large Buildings," Proceedings of First Air Infiltration Centre Conference, Windsor, October, 1980. 
BIBLIOGRAPHIC DATA

SHEET (See instructions)

1. PUBLICATION OR
REPORT NO.
NBSIR $83-2768$

2. Performlng Organ. Report Nof 3. Publication Date

September 1983

4. TITLE AND SUBTITLE

Interim Report on NBS Thermal Integrity Diagnostic Tests on Eight

GSA Federal Office Buildings

5. $A \cup T H O R(S)$

Richard A. Grot, Yui-May Chang, Andrew K. Persily, Jin B. Fang

\begin{tabular}{l|l} 
6. PERFORMING ORGANIZATION (If joint or other than NBS. see Instructions) & 7. Contract/Grant No.
\end{tabular}

NATIONAL BUREAU OF STANDARDS

Interagency Agreement PBS-80-1

DEPARTMENT OF COMMERCE

8. Type of Report \& Period Covered

WASHINGTON, D.C. 20234

9. SPONSORHNG ORGANHZATIOHS NAME AND COMPLETE ADDRESS (Stret, City, Stote, ZIP)

Public Building Service

General Services Administration

Washington, D.C. 20405

10. SUPPLEMENTARY NOTES

[ Document describes a computer program; SF-185, FIPS Software Summary, is attached.

11. ABSTRACT (A 200-word or less factual summary of most significant information. If document includes a significant bibliography or literature survey, mention it here)

This report summarizes preliminary results of diagnostic tests to evaluate the thermal integrity of eight Federal office buildings located throughout the country. The test results include tracer gas measurements of air infiltration rates, pressurization tests of the air tightness of the building shell, and inspections of the envelope employing infrared thermography. In addition, the thermal U-values of exterior walls were measured with both heat flow meters and a portable calorimeter box. The data collected on these buildings are still undergoing analysis and therefore are to be considered preliminary.

12. KEY WORDS (Six to twelve entries; alphabetical order; capitalize only proper names; and separate key words by semicolons) air infiltration; building diagnostics; building thermal integrity; fan pressurization; field measurements; theruographic inspections; tracer gas techniçue; U-value tests

13. AVAILABILITY

[X] Unlimited

For Official Distribution. Do Not Release to NTIS

$\square$ Order From Superintendent of Documents, U.S. Government Printing Office, Washington, D.C. 20402.

X] Order From National Technical Information Service (NTIS), Springfield, VA. 2216I

14. NO. OF PRINTED PAGES

\section{0}

15. Price

$\$ 8.50$ 


